
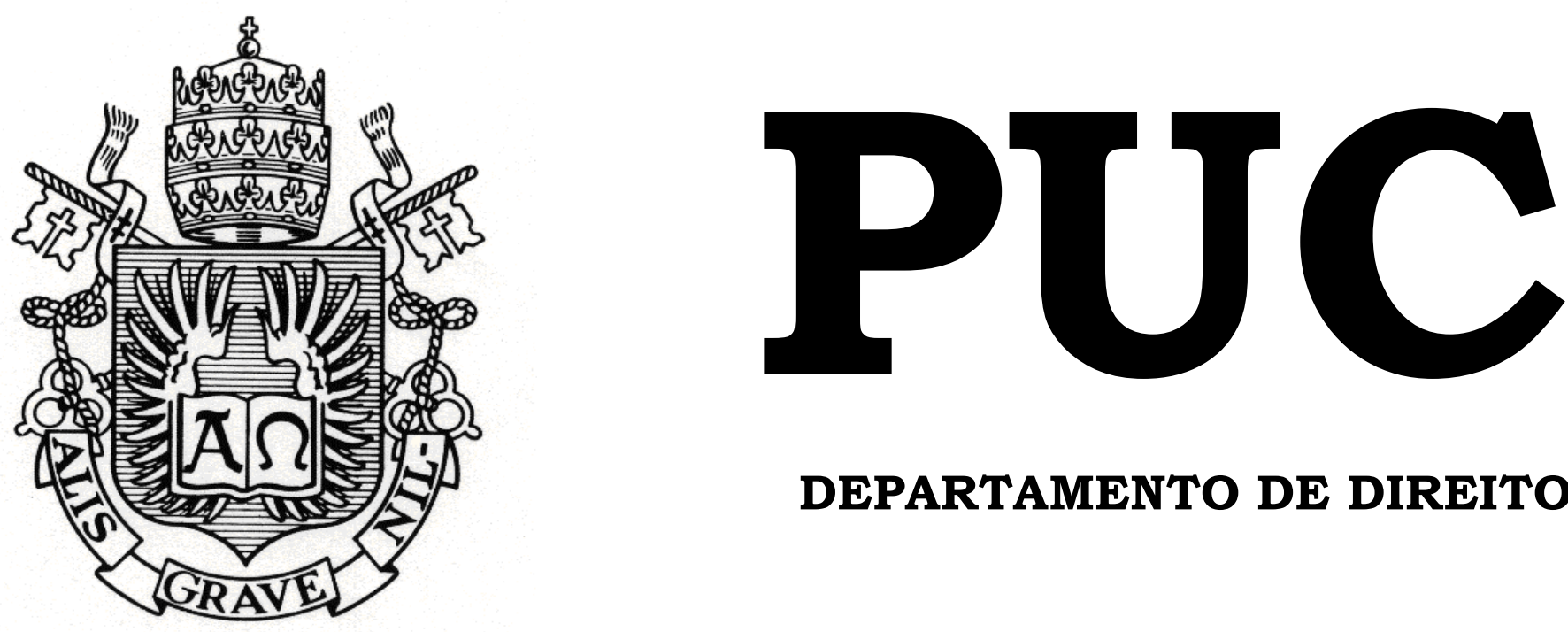

DEPARTAMENTO DE DIREITO

\title{
A AMPLA DEFESA E O DEFENSOR DATIVO NO PROCESSO PENAL CONSTITUCIONAL
}

\author{
por \\ YANNICK YVES ANDRADE ROBERT
}

ORIENTADORA: Victoria-Amália de Barros Carvalho Gozdawa de Sulocki

2010.2

PONTIFÍCIA UNIVERSIDADE CATÓLICA DO RIO DE JANEIRO RUA MARQUÊS DE SÃO VICENTE, 225 - CEP 22453-900 RIO DE JANEIRO - BRASIL 


\section{A AMPLA DEFESA E 0 DEFENSOR DATIVO NO PROCESSO PENAL CONSTITUCIONAL}

por

YANNICK YVES ANDRADE ROBERT

Monografia apresentada ao Departamento de Direito da Pontificia Universidade Católica do Rio de Janeiro (PUC-Rio) para a obtenção do Título de Bacharel em Direito.

Orientadora: Victoria-Amália de Barros Carvalho Gozdawa de Sulocki 


\section{Dedicatória}

À Olorum e todos os Orixás, pelo que são e pelo que representam;

Aos meus antepassados pelo que sou;

À minha mãe, não só pela vida, mas por me mostrar amor e fé pelo Direito desde pequeno;

Ao meu pai pelo que representa para mim;

À minha irmã, pelo exemplo de determinação, superação e lealdade;

À minha avó Maria Marília Fernandes de Andrade, por tudo. 


\section{Agradecimentos}

À minha orientadora Professora Victoria-Amália de Barros Carvalho Gozdawa de Sulocki pela acolhida na realização deste trabalho, pelo incentivo e apoio ao longo da graduação.

Ao Professor Fábio Carvalho Leite pelos três anos de convívio no Programa de Iniciação Científica, bem como a todos os meus colegas do grupo.

À todos os professores do departamento de direito da PUC-RIO pela formação oferecida;

Aos Defensores Públicos Laura Julia Andrade Fontenelle e Eurico de Castro Monteiro Junior pela iniciação na prática do Processo Penal na defesa dos que já perderam ou nunca tiveram esperança na vida;

Aos Professores e Defensores Públicos Marcelo Machado da Fonseca e Luiz Paulo Vieira de Carvalho pela ajuda e força na caminhada rumo ao concurso público;

Aos meus amigos, bens mais preciosos da vida, em especial à Luisa Vianna pelos quinze anos de apoio incondicional no meu dia a dia. 


\section{Resumo}

O Estado Constitucional de Direito surgido após a Segunda Guerra Mundial tem como principal característica a centralidade da Constituição. A constitucionalização do direito é um dos desdobramentos do neoconstitucionalismo, que se realiza, sobretudo, pela interpretação conforme a Constituição, que visa dar efetividade aos mandamentos constitucionais. No Processo Penal significa a incorporação dos valores trazidos pela Carta Constitucional, em especial na adequação dos dispositivos infraconstitucionais ao sistema acusatório consagrado pela Constituição. O direito de defesa é consagrado constitucionalmente desde a Carta de 1891 mas ainda hoje não é assegurado de modo efetivo pelos tribunais. $\mathrm{O}$ presente trabalho busca interpretar à luz do paradigma trazido pela Constituição de 1988 a atuação do defensor dativo no Processo Penal.

\section{Palavras-chaves}

Processo Penal Constitucional; Ampla defesa; Defensor dativo 
$\begin{array}{ll}\text { Introdução } & 8\end{array}$

1- O Processo Penal Constitucional. 10

1.1 - Da Constitucionalização do Direito; 10

1.1.1 - A construção do Modelo Constitucional Brasileiro; 10

1.1.1.1 - Marco histórico: pós-guerra e redemocratização; 10

1.1.1.2 - Marco filosófico: o pós-positivismo; 11

1.1.1.3 - Marco teórico: três mudanças de paradigma; 12

a - A força normativa da Constituição; 12

b - A expansão da jurisdição constitucional; 13

c - A nova interpretação constitucional; 14

1.1.2 - Da constitucionalização do Direito ao Processo Penal Constitucional; 16

1.1.2.1 - Da Constitucionalização do Direito; 16

1.1.2.2 - O Direito Processual Constitucional; 17

1.2 - O Direito Processual Penal e as suas próprias categorias

$\begin{array}{ll}\text { jurídicas. } & 18\end{array}$

1.2.1 - Fundamentos de existência do Direito Processual Penal no Estado Constitucional de Direito; 19

1.2.1.1 - Princípio da necessidade do processo penal em

relação à pena; 19

1.2.1.2 - Instrumentalidade do Processo Penal; 20

1.2.2 - Objeto do Processo Penal: a pretensão acusatória. 22

1.2.2.1 - Noção Carneluttiana de pretensão; 23

1.2.2.2 - Estrutura da pretensão Processual Penal; 24

2 - A Ampla Defesa no Processo Penal Constitucional - o Direito de Defesa como garantia de um processo justo 28

2.1 - Evolução histórica do direito de defesa; 28

2.1.1 - Das ordálias ao sistema acusatório; 28

2.1.2 - Evolução Histórica positiva do Direito de Defesa e da assistência jurídica criminal no Brasil; 35 
2.2 - Definição e natureza jurídica da defesa - direito, princípio ou garantia?

2.2.1 - Definição e natureza jurídica da defesa.

2.2.2 - Direito, princípio ou garantia? 42

2.3 - Conteúdo do direito de defesa;

2.3.1 - Defesa Pessoal (auto-defesa);

2.3.2 - Defesa técnica;

2.3.3 - Relações entre defesa pessoal e defesa técnica;

3 - O Defensor dativo 53

3.1 - Previsão normativa; 53

3.2- Interpretação conforma a Constituição; 55

\section{Conclusão}

61

Bibliografia 


\section{INTRODUÇÃO}

O Código de Processo Penal Brasileiro em vigor foi decretado em 13 de outubro de 1941 por Getúlio Vargas, sob a égide da Constituição de 1937, no Estado Novo, tendo como matriz o Código de Processo Penal Italiano de 1930, conhecido como Código Rocco, símbolo do fascismo de Mussolini.

A redação original do Código trazia inúmeros dispositivos autoritários, ainda sob a inspiração do sistema inquisitivo, prevendo um juiz com amplos poderes instrutórios e podendo, inclusive, ordenar ao promotor que adite a acusação.

Com a redemocratização do Brasil foi promulgada a Constituição de 1988, fruto da soberania popular. É importante frisar que todos os principais ramos do direito tiveram alguns de seus aspectos tratados na Constituição Cidadã ocorrendo o fenômeno da constitucionalização das fontes do Direito que consiste no reconhecimento da força normativa da Constituição, fazendo com que seus princípios sejam a fonte de validade e ponto de partida na interpretação do direito.

Diante da mudança de paradigma hermenêutico, toda a ordem jurídica pré-existente deve ser lida sob a lente da Constituição e passada pelo seu crivo, de modo a realizar os valores nela consagrados. Esse fenômeno, que representou verdadeira revolução copernicana, é chamado pela doutrina de filtragem constitucional.

Em relação ao Processo Penal, a Constituição adotou o sistema acusatório, reconhecendo o réu como sujeito de direitos e conferindo-lhe diversas garantias fundamentais, dentre as quais o direito de defesa de forma ampla, com todos os meios a ele inerentes. Devendo os dispositivos do Código de Processo Penal serem interpretados à luz do novo sistema constitucional.

Vale frisar que o direito de defesa é previsto em sede constitucional como direito e garantia fundamental desde a Constituição de 1891. O Código de Processo Penal prevê desde a sua redação original que nenhum 
acusado pode ser processado e julgado sem defesa. No entanto, com as mudanças ocorridas ao longo das quase sete décadas de vigência do Código, deve-se re-interpretar o direito de defesa, à luz do paradigma trazido pela Constituição cidadã para que seja assegurado de forma efetiva. Observa-se nos tribunais que o direito de defesa é assegurado formalmente, isto é, preocupa-se com a presença de um defensor, mas não com a efetividade de seu trabalho.

O presente trabalho é dividido em três capítulos e busca interpretar à luz do paradigma trazido pela Constituição de 1988 a atuação do defensor dativo no Processo Penal.

O primeiro capítulo trata do Direito Processual Penal Constitucional analisando a constitucionalização do direito, investigando a construção do modelo constitucional Brasileiro e, em uma segunda parte, as categorias jurídicas próprias do Direito Processual Penal, a partir de seus fundamentos de existência e de seu objeto.

O segundo capítulo apresenta um estudo sobre a ampla defesa no Processo Penal Constitucional. Em um primeiro momento é traçada a evolução histórica do direito de defesa para em seguida delinear o seu conteúdo.

O último capítulo trata do defensor dativo, apresentando os dispositivos do Código de Processo Penal que prevêem a sua atuação, sendo proposta uma interpretação dos dispositivos à luz do modelo constitucional explicitado no primeiro capítulo e das considerações feitas no segundo. 


\section{1 - O PROCESSO PENAL CONSTITUCIONAL}

\section{1 - Da constitucionalização do Direito;}

\subsection{1 - A Construção do Modelo Constitucional Brasileiro Contemporâneo;}

Ao longo do século XIX, ainda sob os ares da Revolução Francesa, consolidou-se o Estado de Direito na Europa, tendo como características a separação de poderes e a proteção dos direitos individuais. Este modelo de Estado expressa a noção de governo de leis, em clara oposição ao modelo anterior de governo "dos homens" onde o soberano é quem ditava as regras às quais se submeteria. No novo modelo, o administrador é submetido às regras postas.

De acordo com Luis Roberto Barroso, a partir do término da Segunda Guerra Mundial desenvolve-se o Estado Constitucional de Direito, tendo como característica central a subordinação da legalidade a uma Constituição rígida. Atribui-se à Constituição o fundamento de validade das demais normas do ordenamento jurídico. Nesse contexto, de acordo com o autor:

"A ciência do Direito assume um papel crítico e indutivo da atuação dos Poderes Públicos, e a jurisprudência passa a desempenhar novas tarefas, dentre as quais se incluem a competência ampla para invalidar atos legislativos ou administrativos e para interpretar criativamente as normas jurídicas à luz da Constituição"1.

Com base na sistematização proposta pelo Professor Barroso, serão apresentados nos tópicos seguintes os marcos teóricos que permitiram a construção do modelo de Estado Constitucional de Direito contemporâneo, rompendo-se com o modelo anterior.

\subsubsection{1 - Marco histórico: pós-guerra e redemocratização;}

O marco histórico do Direito Constitucional Europeu foi o Constitucionalismo do pós-guerra, especialmente na Alemanha e na Itália.

\footnotetext{
1 BARROSO, Luis Roberto. Curso de Direito Constitucional Contemporâneo: os conceitos fundamentais e a construção do novo modelo. São Paulo: Saraiva, 2009. pg. 245.
} 
No Brasil, a Constituição de 1988 é um marco no processo de redemocratização.

Na Europa, após o trauma da segunda-guerra mundial, destaca-se a Lei Fundamental de Bonn de 1949 como marco inicial do novo paradigma constitucional, sobretudo após a instalação do Tribunal Constitucional Alemão em 1951, a partir de quando teve inicio uma fecunda produção teórico e jurisprudencial, responsável pela ascensão científica do Direito Constitucional. Destaca-se ainda na Europa a Constituição da Itália de 1947, bem como os processos de redemocratização de Portugal em 1976 e da Espanha em 1978, ganhando mais espaço o novo Direito Constitucional.

De acordo com Barroso, o novo Constitucionalismo europeu caracteriza-se pelo "reconhecimento de força normativa às normas constitucionais, rompendo com a tradição de se tornar a Constituição como documento antes político que jurídico, subordinado às circunstancias do Parlamento e da Administração" .

No Brasil, destaca-se como marco o processo de redemocratização, após vinte anos de Ditadura Militar, a convocação da Assembléia Nacional Constituinte em 1985 que culminou na Constituição de 1988.

\subsubsection{2 - Marco filosófico: o pós-positivismo.}

O marco filosófico do Direito Constitucional contemporâneo é o póspositivismo, que surge como reação ao positivismo, que por sua vez conferiu legalidade ao fascismo na Itália e ao nazismo na Alemanha.

O positivismo dominou o pensamento jurídico da primeira metade do século XX. Equiparava Direito à lei, afastando-o das discussões filosóficas e de discussões como legitimidade e justiça.

A doutrina pós-positivista se inspira na revalorização da razão prática em contraste com a razão teórica -, na teoria da justiça e na legitimação democrática. De acordo com Barroso o pós-positivismo, "busca ir além da

\footnotetext{
${ }^{2}$ Ibid, pg. 246.
} 
legalidade estrita, mas não despreza o direito posto; procura empreender uma leitura moral da Constituição e das leis, mas sem recorrer a categorias metafísicas"”.

Nesse paradigma, promove-se a reaproximação entre o Direito e a Moral, reinserindo-se os valores na interpretação jurídica, reconhecendo-se normatividade aos princípios. Forma-se uma nova hermenêutica e um teoria dos direitos fundamentais edificada sobre a dignidade da pessoa humana. $\mathrm{O}$ novo direito constitucional ou neoconstitucionalismo é em parte o produto desse reencontro entre a ciência jurídica e a filosofia do Direito. Os valores morais compartilhados por toda a comunidade, em dado momento e lugar materializam-se em princípios, que passam a estar abrigados na Constituição, explícita ou implicitamente.

\subsubsection{3 - Marco Teórico: três mudanças de paradigma.}

No plano teórico, Luis Roberto Barroso noticia três grandes transformações que subverteram o método tradicional de aplicação do Direito Constitucional: a) o reconhecimento de força normativa à Constituição; b) a expansão da jurisdição constitucional; c) o desenvolvimento de uma nova dogmática da interpretação constitucional. A seguir, alguns comentários sobre os itens apontados.

\section{a - A força normativa da Constituição.}

Até meados do século $\mathrm{XX}$, a Constituição era vista como um documento meramente político. A concretização de seus valores ficava à discricionariedade do Administrador e do Legislador. Ao Judiciário não se reconhecia qualquer papel relevante na realização do conteúdo da Constituição.

\footnotetext{
${ }^{3}$ Ibid. pg. 249.
} 
O cenário é alterado com a reconstitucionalização que sobreveio à Segunda Guerra Mundial, inicialmente na Alemanha, destacando-se o trabalho de Konrad Hesse, em especial a aula inaugural proferida na cátedra da Universidade de Freiburg em 1959 que se transformou no clássico "A força normativa da Constituição" traduzido para o português por Gilmar Ferreira Mendes.

Como assinala Barroso, atualmente, é premissa do estudo da Constituição o reconhecimento de sua força normativa, do caráter vinculativo e obrigatório de suas disposições. Sendo espécie de norma jurídica, as normas constitucionais são dotadas de imperatividade, e sua inobservância há de deflagrar os mecanismos de coação e de cumprimento forçado.

No Brasil, o debate acerca da força normativa da Constituição chega apenas no final dos anos 80, com a Carta de 1988. Todavia, destaca-se na doutrina nacional a tese de José Afonso da Silva Aplicabilidade das normas Constitucionais, publicada em 1968, que teve o mérito de reconhecer de distinguir as aplicabilidade de eficácia das normas constitucionais e sobretudo de reconhecer que determinadas normas constitucionais possuem aplicabilidade direta e imediata.

\section{b - A expansão da jurisdição constitucional.}

Até a Segunda Guerra Mundial vigorava na Europa o modelo de supremacia do Poder Legislativo. Com o final da Guerra, inaugura-se um novo modelo constitucional, não apenas com um novo texto, mas sobretudo por reconhecer-lhe supremacia sobre as demais normas. Trata-se do modelo da supremacia da Constituição, que vai além do positivismo por proteger o seu núcleo fundamental, inclusive da vontade da maioria. A proteção da Constituição incumbe ao Poder Judiciário, que tem legitimidade para declarar leis incompatíveis com a Constituição. 
Desenvolveram-se inúmeros modelos de jurisdição constitucional. Em alguns Estados atribui-se à um único órgão do Poder Judiciário o poder de declarar as leis inconstitucionais. Trata-se do controle concentrado, surgido historicamente na Áustria. De outro modo, no modelo difuso de controle de constitucionalidade, qualquer órgão do Poder Judiciário pode declarar a lei inconstitucional, que surge historicamente nos Estados Unidos da América, no caso Marbury v. Madison, julgado pela Suprema Corte americana em 1803.

O Brasil segue os dois modelos. O controle difuso vem desde a primeira Constituição Republica e subsiste até hoje. Todos os órgãos do Poder Judiciário, do juiz estadual recém concursado ao Presidente do Supremo Tribunal Federal têm o dever de recusar a aplicação às leis incompatíveis com a Constituição da República ${ }^{4}$. O controle concentrado de constitucionalidade foi introduzido pela Emenda Constitucional 16 de 1965 que previu uma ação genérica a ser ajuizada pelo Procurador Geral diretamente no Supremo Tribunal Federal. Hoje, o controle de constitucionalidade por ser exercido de forma concentrada perante o Supremo Tribunal Federal, mediante ação direta de inconstitucionalidade, ação declaratória de constitucionalidade ou argüição de descumprimento de preceito fundamental. $\mathrm{Na}$ via difusa, qualquer órgão do Poder Judiciário deve se recusar a aplicar no caso concreto leis que considerem incompatíveis com a Constituição, com a única ressalva para a cláusula reserva de plenário para os órgão colegiados, prevista no art. 97 da Constituição da República.

\section{c - A nova interpretação constitucional.}

Diante de todas as mudanças acima numeradas, não seria mais possível continuar a interpretar o texto constitucional da mesma forma, utilizando os

\footnotetext{
${ }^{4}$ BARROSO, Luis Roberto. O Controle de Constitucionalidade no Direito Brasileiro. $2^{\mathrm{a}}$ edição. São Paulo: Saraiva, 2007.
} 
métodos clássicos de interpretação, concebidos em uma época onde a Carta era um documento político. Necessita-se interpretar o ordenamento jurídico de modo que a Constituição seja o ponto de partida do processo interpretativo.

Vale mencionar que a norma jurídica é o resultado do processo interpretativo, sendo o dispositivo o ponto de partida.

Nesse contexto, destacam-se na doutrina os chamados princípios instrumentais de interpretação constitucional, que constituem premissas conceituais, metodológicas ou finalísitcas que devem anteceder, no processo intelectual do interprete, a solução concreta da questão posta ${ }^{5}$. Vale mencionar que parte da doutrina ${ }^{6}$ recusa o termo princípio, criando uma terceira categoria normativa: os postulados normativos, que seriam instrumentos metódicos que imporiam condições a serem observadas na aplicação das regras e dos princípios, não se confundindo com estes. Optaremos por usar a expressão princípios, empregada por Luis Roberto Barroso, por ser o autor usado como base nesse estudo.

Dentre os princípios enumerados pela doutrina, destacamos a seleção feita por Luis Roberto Barroso ${ }^{7}$, quais sejam: princípio da supremacia da Constituição; princípio da presunção de constitucionalidade das leis e atos do Poder Público; princípio da interpretação conforme a Constituição; princípio da unidade da Constituição; princípio da razoabilidade ou proporcionalidade.

Como consequiência do novo modelo constitucional, impõe-se a revisão de todo o ordenamento jurídico, em especial dos ramos infraconstitucionais do direito, tema tratado na próxima seção.

\footnotetext{
${ }^{5}$ BARROSO, Luis Roberto. Curso de Direito Constitucional Contemporâneo, p. 298

${ }^{6}$ AVILA, Humberto. Teoria dos princípios, da definição à aplicação dos princípios jurídicos. $5^{\mathrm{a}}$ edição. São Paulo: Malheiros Editores, 2006.

7 BARROSO, Luis Roberto. Interpretação e aplicação da Constituição. $6^{\mathbf{a}}$ edição. São Paulo: Saraiva.
} 


\subsection{2 - Da Constitucionalização do Direito ao Processo Penal Constitucional;}

\subsubsection{1 - Da Constitucionalização do Direito;}

A locução constitucionalização do Direito é de uso recente e será empregada no presente trabalho como um efeito expansivo das normas constitucionais, cujo conteúdo material e axiológico se irradia, com força normativa, por todo o sistema jurídico ${ }^{8}$. Trata-se de reconhecer aplicação prática dos marcos teóricos do Constitucionalismo contemporâneo.

No Brasil, a Carta de 1988, como já assinalado, tem a virtude de simbolizar a redemocratização brasileira, após vinte anos de ditadura militar onde foram subtraídas diversas garantias fundamentais. Quanto ao ponto tratado, é bem de ver que todos os principais ramos do direito infraconstitucional tiveram aspectos sues tratados na Constitucional. A catalogação se estende dos princípios gerais até as regras miúdas. No Direito Processual Penal, a Constituição enuncia no capítulo sobre direitos individuais e coletivos, diversas regras, princípios e garantias do processo penal como o devido processo legal, publicidade, motivação das decisões judiciais, presunção de inocência, individualização da pena, entre outras.

No entanto, cumpre assinalar que, como adverte o Professor Barroso, o fenômeno da constitucionalização do Direito não se confunde com a presença de normas de direito infraconstitucional na Constituição, representando uma constitucionalização das fontes do Direito naquela matéria, fenômeno que nem sempre é desejável por representar um limite de atuação do legislador ordinário.

$\mathrm{Na}$ constitucionalização do direito infraconstitucional, a Constituição passa a ser vista não apenas um sistema em si, mas também um modo de olhar e interpretar os demais ramos do Direito. Esse fenômeno, chamado por alguns autores como filtragem constitucional, consiste em que toda a

\footnotetext{
${ }^{8}$ BARROSO, Luis Roberto. Curso de Direito Constitucional Contemporâneo.
} 
ordem jurídica deve ser lida e apreendida sob a lente da Constituição, de modo a realizar os valores nela consagrados ${ }^{9}$. Assim, toda interpretação jurídica é também interpretação constitucional e qualquer operação de aplicação do Direito envolve a aplicação direta ou indireta da Constituição.

Nesse ponto, afirma Luis Roberto Barroso:

"a Constituição figura hoje no centro do sistema jurídico, de onde irradia sua força normativa, dotada de supremacia formal e material. Funciona, assim, não apenas como parâmetro de validade para a ordem infraconstitucional, mas também, como vetor de interpretação de todas as normas do sistema"10.

Dessa forma, a norma jurídica deve ser o resultado da interpretação do direito posto à luz da Constituição da República, através dos princípios interpretativos mencionados acima.

Passa-se a seguir, a analisar a constitucionalização Do Direito Processual Penal, o que se denominou chamar de Direito Processual Constitucional.

\subsubsection{2 - O Direito Processual Penal Constitucional.}

Na linha de raciocínio até então desenvolvida, o Direito Processual Penal Constitucional seria a interpretação das normas processuais penais à luz da Constituição da República.

Nesse ponto, deve-se citar Ada Pellegrini Grinover, Antonio Carlos de Araújo Cintra e Candido Rangel Dinamarco, em obra que é referencia no Direito Processual Civil e Penal Brasileiro, de acordo com os quais:

"Hoje acentua-se a ligação entre processo e Constituição no estudo concreto dos institutos processuais, não mais colhidos na esfera fechada do processo, mas no sistema unitário do ordenamento jurídico: é esse o caminho, foi dito com muita autoridade, que transformará o processo, de simples instrumento de justiça, em garantia de liberdade". ${ }^{11}$

\footnotetext{
${ }^{9}$ Ibid.

${ }^{10}$ Ibid., p. 363.

${ }^{11}$ CINTRA, Antonio Carlos de Araujo, et. Al. Teoria Geral do Processo. 23 $3^{\text {a }}$ edição. São Paulo: Malheiros, 2007, p. 84.
} 
No Processo Penal Brasileiro, a afirmação acima ganha especial relevância pelo fato do Código de Processo Penal ter sido promulgado por Getúlio Vargas, por meio de um Decreto-Lei em 194, no auge do Estado Novo. Como visto, a Carta de 1988 rompe com o paradigma Constitucional vigente e, como fruto do processo de redemocratização traz inúmeras garantias fundamentais, e consagra um novo sistema processual penal: o sistema acusatório, conforme será visto no próximo item.

Dessa forma, como visto, as normas processuais penais postas devem passar pela filtragem da Carta de 1988 para serem aplicadas. Em outras palavras, o intérprete somente poderá aplicar os dispositivos processuais se estiverem em consonância com a Constituição da República, não o estando, devem ser interpretadas a fim de se construir a norma processual constitucional.

Um dos resultados da constitucionalização do direito processual penal é o reconhecimento do sistema acusatório como opção do Constituinte, o que traz uma série de conseqüências que serão abordadas nos próximos capítulos.

\section{2 - O Direito Processual Penal e as suas próprias categorias jurídicas.}

Para entender-se o Direito Processual Penal e suas peculiaridades, parte-se da premissa de Aury Lopes Junior de que o Direito Processual Penal possui categorias jurídicas próprias, sendo inviável conceber uma Teoria Geral do Processo que sirva tanto para o Direito Processual Civil e Processual Penal.

A partir dessa perspectiva, sem, contudo ter a pretensão de exaurir o tema, demonstra-se a seguir, com fulcro na sistematização proposta por Aury Lopes Junior, os fundamentos de existência do Direito Processual Penal no Estado Constitucional de Direito bem como justificaremos a pretensão acusatória, como objeto do Processo Penal, com o objetivo de 
compreendermos, no próximo capítulo a amplitude e o conteúdo do Direito de Defesa.

\subsection{1 - Fundamentos de existência do Direito Processual Penal no Estado Constitucional de Direito;}

A partir das conclusões postas na seção anterior, pode-se afirmar, com Aury Lopes Junior, que o que necessita ser legitimado é o poder de punir, a intervenção estatal e não a liberdade individual, premissa posta pela Carta de 1988. O processo não pode ser visto como um simples instrumento a serviço do poder punitivo, senão que desempenha o papel de limitador do poder e garantidor do individuo a ele submetido ${ }^{12}$.

É sempre oportuno lembrar que sem embargos de ter sido tratado na primeira parte deste capítulo, a Constituição da República é o fundamento de existência do processo penal, isto é, é o seu ponto de partida e filtro axiológico.

\subsubsection{1 - Princípio da necessidade do processo penal em relação à pena.}

O Estado avocou para si a titularidade exclusiva do direito (e dever) de punir ao proibir a auto-tutela, suprimindo a vingança privada. O Estado detém o monopólio da Justiça. Com isso, o processo perde a natureza contratual (litiscontestatio) e passa a ser o meio oferecido pelo Estado para a solução do conflito. Nessa perspectiva, ocorrendo a violação de um bem juridicamente protegido, não resta outra solução ao particular senão invocar a tutela jurisdicional do Estado.

No Direito Privado, as partes aplicam as normas de direito material diretamente, sem maiores problemas, celebrando negócios jurídicos e praticando atos jurídicos em sua vida diária. O Estado somente será

\footnotetext{
${ }^{12}$ JUNIOR, Aury Lopes. Direito Processual Penal e sua conformidade Constitucional. $5^{\text {a }}$ edição. Rio de Janeiro: Lumen Juris, 2010.
} 
chamado a aplicá-lo coercivamente, através do Processo, caso ocorra um litígio, hipótese em que atuará substituindo a vontade das partes, adjudicando ao vencedor o bem da vida pretendido.

Com o Direito Penal é diferente, embora os tipos penais tenham uma função de prevenção geral e também de proteção, sua verdadeira essência está na pena, no preceito secundário, que não pode prescindir do processo para a sua aplicação. O Direito Penal não tem coerção direta de modo que não tem atuação concreta fora do processo ${ }^{13}$. Hoje, existe um monopólio dos órgãos jurisdicionais na aplicação da pena.

A pena é concebida como conseqüência jurídica do delito, de modo que depende da existência do delito e da existência efetiva e total do processo tendo em vista que se o processo termina antes de desenvolver-se completamente (ex: arquivamento, suspensão do processo) ou se não se desenvolve de forma válida, não pode ser imposta uma pena.

Desse modo, não existe delito sem pena, nem pena sem delito e processo, nem processo penal senão para determinar o delito e impor uma pena. O processo penal é o caminho necessário para a aplicação da pena. O processo penal é a única estrutura que se reconhece como legitima para a imposição da pena. É o que se denominou chamar de princípio da necessidade do processo penal que resulta da efetiva aplicação do adágio latino nulla poena et nulla culpa sine iudicio ${ }^{14}$.

\subsubsection{2 - Instrumentalidade do Processo Penal.}

É cediço na doutrina hoje que o processo não é um fim em si mesmo, que representa sempre um instrumento. Inobstante parte-se da premissa de que não existe uma teoria geral do processo, deve-se fazer referencia à Ada Pellegrini Grinover, Antonio Carlos de Araujo Cintra e Candido Rangel Dinamarco, in Teoria Geral do Processo, de acordo com os quais, a

\footnotetext{
${ }^{13} \mathrm{Ibid}$

${ }^{14}$ Ibid.
} 
instrumentalidade do processo deve ser vista sob um prisma positivo e negativo.

Em seu aspecto positivo, a instrumentalidade impõe que se observem os escopos sociais, políticos e jurídicos do processo, em especial a máxima de que o processo é um "instrumento a serviço da paz social", uma vez que visa a solução do litígio.

Pelo seu aspecto negativo, a instrumentalidade consiste em alertar para o fato de que o processo não é um fim em si mesmo, de modo que não deve ser dada mais importância às regras de direito processual do que as de direito material, do qual é instrumento. Nessa perspectiva, pode-se afirmar que o direito processual está a serviço da satisfação da pretensão.

Em relação ao Processo Penal, resta definir o conteúdo do instrumento, ou a serviço de que ou quem o processo está. Não se pode afirmar que o processo penal seja um instrumento de uma única finalidade, a satisfação de uma pretensão (acusatória) sob pena de tornar-se um instrumento autoritário e incompatível com a ordem Constitucional.

Geraldo Prado ${ }^{15}$ adverte que o processo tem uma função constitucional como instrumento a serviço da realização do projeto democrático, de modo que o conteúdo da instrumentalidade do processo penal deve ser vista à luz da Constituição da República.

Todavia, como destaca Aury Lopes Junior ${ }^{16}$, deve-se ter cuidado na definição nas metas do Processo Penal pois não pode ser usado como instrumento de "segurança pública". Como exemplifica o autor, torna-se abusivo a decretação de prisão preventiva para garantia da ordem pública por tratar-se de fim alheio ao processo.

É fundamental deixar assentado que na democratização do processo penal, o sujeito passivo deixa de ser visto como um mero objeto, passando a

\footnotetext{
${ }^{15}$ PRADO, Geraldo. Sistema acusatório - A Conformidade Constitucional das leis processuais penais. $4^{a}$ edição. Rio de Janeiro: Lumen Juris, 2006.

${ }^{16}$ JUNIOR, Aury Lopes. Op. Cit.
} 
ocupar uma posição de destaque enquanto parte, com verdadeiros direitos e deveres ${ }^{17}$.

Assim, conclui-se com Aury Lopes Junior que a instrumentalidade do Processo Penal tem por conteúdo a máxima eficiência dos direitos e garantias fundamentais da Constituição, à luz do valor absoluto da dignidade da pessoa humana. Trata-se de uma limitação do poder do punitivo estatal, de modo que o processo, enquanto meio necessário à aplicação da pena, somente estará legitimado se estiver a serviço dos direitos e garantias fundamentais. Eis a instrumentalidade do Processo Penal.

$\mathrm{Na}$ exposição das categorias próprias do Direito Processual Penal, passa-se a seguir à definição de seu objeto.

\subsection{2 - Objeto do Processo Penal: a pretensão acusatória.}

Nesse item, parte-se da premissa de Aury Lopes Junior, de que o objeto do processo é a matéria sobre a qual recai o complexo de elementos que integram o processo, não se confundindo com o seu fundamento (instrumentalidade constitucional) nem com a sua função, ou fim (satisfação jurídica da pretensão ou resistência).

Para o autor, o princípio da necessidade afasta o conceito de lide conflito de interesses qualificado pela pretensão resistida - do Processo Penal uma vez que este será sempre a via necessária para a aplicação da pena. Não é possível ter uma pena sem uma sentença válida. Ou seja, mesmo que não haja um conflito de interesses, o Processo será necessário.

Nessa linha, deve-se deixar claro como premissa que o processo penal constitui um instrumento neutro da jurisdição, de modo que o processo terá atingido a sua finalidade tanto com a condenação como com a absolvição tendo em vista que encontram-se em igualdade a pretensão e a resistência.

\footnotetext{
${ }^{17}$ JUNIOR, Aury Lopes. Op. Cit. p. 14.
} 
É fundamental construir-se um objeto próprio para o Processo Penal na medida em que utilizar as categorias do Processo Civil destoa do modelo traçado pela Constituição para o Processo Penal na medida em que o Ministério Público assumiria a posição de credor de uma pena e que na hipótese de absolvição, o Processo não teria atingido o seu escopo, uma vez que o sujeito ativo não teria satisfeita a sua pretensão.

\subsubsection{1 - Noção Carneluttiana de pretensão;}

Na acepção Carneluttiana, a pretensão é a exigência de subordinação do interesse alheio ao interesse próprio que nasce do conflito de interesses qualificado pela pretensão resistida - lide. Nessa perspectiva, a existência da lide seria um traço característico e continuo na atividade jurisdicional, sobretudo quando tratar-se de pretensões insatisfeitas que poderiam ser satisfeitas pelo obrigado. É a existência de um conflito de interesses que leva o interessado a dirigir-se ao Estado-juiz e pedir uma solução e seria a contraposição dos interesses em conflito que exigiria a substituição dos sujeitos em conflito pelo Estado ${ }^{18}$.

Ao transpormos tal conceito para o Processo Penal, chega-se a afirmação que já está enraizada na prática forense; o Ministério Público deduz em juízo uma pretensão punitiva. Explicite-se o conceito de lide penal, para quem defende a sua existência: a um direito subjetivo do Estado de punir que o Ministério Público deduziria em juízo, em oposição, teríamos a liberdade do acusado. O conflito de interesses - lide - estaria entre o direito de punir do Estado e a liberdade do acusado, o que seria levado a juízo.

Como afirmado anteriormente, não existe uma exigência punitiva que possa ser realizada fora do processo penal, logo, não existe conflito de interesses. A lesão a um bem jurídico não gera um direito subjetivo que possa ser exercido, pois não existe punição fora do processo penal. Como

\footnotetext{
${ }^{18}$ CINTRA, Antonio Carlos de Araujo, et. al. Op. Cit.
} 
assevera Aury Lopes Junior ${ }^{19}$, no Direito Processual Penal não existe um direito para adjudicar (como no cível) fora do Processo Penal que possa produzir a lide pelo conflito de interesses qualificado pela resistência. Dessa forma, o que existe no processo é uma tensão entre acusação e defesa, não uma lide.

A lesão a um bem jurídico gera de imediato o direito do Estado de submeter o suspeito a um juízo cognitivo necessário - o processo penal apenas este. O direito de punir somente surgirá após o regular desenvolvimento do processo, e apenas se for condenado.

O Processo Penal é todo estruturado em torno da acusação. Afirma-se com Aury Lopes Junior que não é a pena o conteúdo ou o objeto do processo penal, senão a sua conseqüência. Desse modo, como assevera o autor, na busca de categorias próprias ao Processo Penal, deve-se desenvolver o conceito de pretensão acusatória como objeto do processo penal, cuja estrutura será analisada no próximo item.

\subsubsection{2 - Estrutura da Pretensão Processual Penal.}

De acordo com Aury Lopes Junior, a pretensão processual é uma declaração petitória (ou afirmação) de que o autor tem direito a que se atue a prestação pedida. No Processo Penal, é uma declaração de que existe o direito potestativo de acusar, pedindo ao fim a aplicação do poder punitivo estatal. Trata-se de uma pretensão acusatória, que nasce da lesão a um bem jurídico.

Para Aury Lopes Junior três elementos compõem a pretensão acusatória: subjetivo, objetivo e a declaração petitória, que passaremos a analisar na sistematização proposta pelo autor.

O elemento subjetivo diz respeito aos entes que figuram como titulares: o pretendente e aquele contra quem se pretende fazer a pretensão. No Processo Penal, quem formula a pretensão pode ser o próprio Estado

\footnotetext{
${ }^{19}$ JUNIOR, Aury Lopes. Op. Cit.
} 
representado pelo Ministério Público ou a vítima nos delitos de ação penal de iniciativa privada. No pólo passivo da relação processual está o acusado, pessoa contra quem é formulada a pretensão.

O elemento objetivo da pretensão no processo penal é o fato aparentemente punível, a conduta que reveste uma verossimilitude de tipicidade, ilicitude e culpabilidade, o fummus comissi delicti. Vale frisar que este é apenas um dos elementos integrantes da pretensão.

Nesse ponto, vale aclarar que se o fato deduzido em juízo não for aparentemente típico, ilícito ou culpável, a pretensão deverá sequer ser deduzida em juízo, seja rejeitando a inicial acusatória na forma do art. 395 do CPP, ou absolvendo o acusado sumariamente na forma do art. 397 do CPP.

Interessante discussão sobre o elemento objetivo da pretensão, em especial sobre a sua individualização é sobre o princípio do jura novit curia, segundo o qual, ao acusador cabe apenas narrar o fato, para que o juiz diga o direito aplicável. Aparentemente, teria sido este o sistema adotado pelo legislador Brasileiro por força do artigo 383 do Código de Processo Penal. Tradicionalmente se afirma que não haveria ofensa à Defesa posto que o acusado se defende dos fatos e não da qualificação jurídica atribuída pela acusação. Ocorre que na maior parte dos casos, não pode o defensor deduzir toda a matéria de defesa sobre todas as qualificações jurídicas possíveis ao fato descrito na denúncia sob pena de entrar em contradição, de construir teses colidentes. Nessa perspectiva, haverá ofensa à ampla defesa e ao contraditório quando o Magistrado der definição jurídica diversa aos fatos narrados na denúncia da atribuída pelo Parquet.

De igual modo, no Direito Processual Civil afirma-se tradicionalmente que a demanda seria individualizada apenas pelos fatos narrados pelo autor, incumbindo ao juiz extrair desses o direito. Todavia, em posição de vanguarda, Leonardo Greco defende que a qualificação jurídica dada à causa de pedir pelo autor não pode ser alterada pelo Magistrado sob pena de ofensa às garantias constitucionais do processo. Vale transcrever as 
palavras do Professor: "Não me parece aceitável o jura novit cúria, pois o juiz não pode dar aos fatos que o autor relatou uma configuração jurídica diferente e o réu tem o direito de se defender da hipótese jurídica que o autor propôs" ${ }^{20}$.

No Processo Penal, pela natureza dos interesses em discussão e por estar em risco a liberdade do acusado, justifica-se ainda mais a necessidade de conferirmos à qualificação jurídica uma maior rigidez, não podendo o magistrado alterá-la no momento da sentença sob pena de ofensa aos princípios da ampla defesa e do contraditório.

Dessa forma, integra o elemento objetivo da pretensão não só o fato em si imputado ao acusado com toda a sua descrição e circunstâncias, como também a sua qualificação jurídica.

O terceiro elemento da pretensão processual, nas palavras de Aury Lopes Junior é o "ato capaz de causar a modificação da realidade que a pretensão leva consigo"21. É o conteúdo petitório, a declaração de vontade que pede a realização da pretensão. É o pedido, que no processo penal é sempre igual, pede-se a condenação do acusado pelo fato narrado e conforme a pena estabelecida no respectivo tipo penal abstrato.

Assentados os elementos que estruturam a pretensão processual penal, cumpre deixar claro o seu conteúdo: acusatória. O titular da pretensão acusatória será o Ministério Público ou o particular. Ao acusador (público ou privado) corresponde apenas o poder de invocação (acusação), o Estado é o titular do poder de punir, que será exercido no Processo Penal através do Juiz - imparcial.

Por fim, vale frisar que no Processo Penal existe um juízo de préadmissibilidade da própria acusação. Trata-se de um juízo de probabilidade que se revela de grande importância tendo em vista que o processo penal por si mesmo já traz conseqüências negativas para o acusado. A pretensão acusatória para ser deduzida em juízo deve vir lastreada em provas de

\footnotetext{
${ }^{20}$ GRECO, Leonardo. Instituições de processo civil. Volume I. $2^{\mathrm{a}}$ edição. Rio de Janeiro: Forense, 2010, página 204.

${ }^{21}$ JUNIOR, Aury Lopes. Op. Cit.
} 
autoria e materialidade sob pena de não ser admitida, na forma do art. 395, III do CPP. 


\section{2 - A AMPLA DEFESA NO PROCESSO PENAL CONSTITUCIONAL - O DIREITO DE DEFESA COMO GARANTIA DE UM PROCESSO JUSTO}

\section{1 - Evolução histórica do direito de defesa;}

$\mathrm{O}$ instinto de defesa é inerente a todos os animais. Quem se sente ameaçado buscará se defender da forma que puder. Antes do Estado assumir o monopólio da Justiça e do uso legítimo da violência, a punição repousava nas mãos do próprio lesado, que buscava retribuir o mau causado. Nesse cenário primitivo, o agressor se defendia com emprego de força. Era a autodefesa. A defesa é um instinto inato ao ser humano, presente desde os primórdios da humanidade. No primeiro julgamento do ser humano foi-lhe assegurada a autodefesa. Deus não condenou Adão sem ouví-lo. Todavia, a evolução social demonstra que a defesa nem sempre foi reconhecida como um Direito.

Torna importante a análise da evolução do direito de defesa a partir do momento em que foi suprimida a vingança privada. Paulatinamente observa-se atribuindo-se a necessidade de um julgamento, no contexto dos diversos sistemas processuais que se sucederam ao longo dos séculos. Impende ainda analisar a evolução histórica do direito positivo brasileiro no que diz respeito ao direito de defesa e a assistência judiciária.

\subsection{1 - Das ordálias ao sistema acusatório.}

$\mathrm{Na}$ antiguidade, dentre as primeiras sociedades organizadas, o Egito revelava o exercício do Poder Judiciário concentrado nas mãos dos sacerdotes. Havia um tribunal supremo encarregado de julgar os crimes mais graves e um juiz em cada província responsável pelo processo e julgamento de "crimes leves". De acordo com Geraldo Prado ${ }^{22}$, encontramos nessa sociedade um "embrião do procedimento inquisitório"

\footnotetext{
${ }^{22}$ PRADO, Geraldo. Op. Cit.
} 
onde a iniciativa oficial para a persecução processual resta ao domínio do sacerdote, quem também o julgará.

Em Atenas observa-se a existência de quatro jurisdições criminais: a Assembléia do povo, o Aerópago, os Efetas e os Heliastas. A competência de cada uma delas era definida pelo tipo de infração cometida, bem como pela pessoa que era julgada. Inobstante serem variáveis os procedimentos adotados em cada Jurisdição, Geraldo Prado $^{23}$ destaca algumas características em comum: tribunal popular - soberania do povo; acusação popular; publicidade e oralidade do juízo; admissão da tortura e dos juízos de Deus como meio de realização probatória; irrecorribilidade das decisões judiciais; valoração da prova de acordo com a intima convicção de cada juiz e, a igualdade entre acusador e acusado. Nesse cenário cumpre destacar que a Defesa tem um papel fundamental, pois há um debate entre acusação e defesa sendo facultado àquela modificar o ânimo dos julgadores.

Em Roma ${ }^{24}$, sucederam-se 3 sistemas procedimentais penais na antiguidade. O mais antigo - cognitio - tem natureza pública, era realizado em nome do Estado romano, deixando o magistrado, enquanto representante do Estado, com amplos poderes de iniciativa, de instrução e julgamento, sem maiores formalidades. Nesse modelo, toda decisão condenatória era passível de apelação pelo acusado ao povo, com efeito suspensivo da sentença. Deflagrando o procedimento de segundo grau, seria julgado pelas Assembléias do Povo. Esse sistema se tornou insuficiente para a repressão da criminalidade por conta de sua ineficiência. $\mathrm{O}$ processo nunca chegava ao fim.

Em seguida, surgiu a accusatio que tinha por característica a ausência de acusador privado. A acusação era uma faculdade concedida a qualquer cidadão, em especial o ofendido, desde que estivesse munido de provas. Era um modelo de processo público e oral, onde os debates formavam o eixo do procedimento. Pode-se afirmar que nesse momento o Processo tomou a 
forma acusatória, era dominado pelo contraditório, cumprindo às partes pesquisarem e produzirem as provas de suas alegações. O mérito desse sistema, nas palavras de Geraldo Prado, foi o de "ter substituído o sentido subjetivo, mítico da prova pelo conhecimento objetivo, histórico, encarando-se a prova como forma de reconstrução de um acontecimento pelos vestígios que havia deixado no mundo" ${ }^{25}$. Todavia, o sistema não se mostrou suficiente para as exigências de repressão da delinquiência, bastava que ninguém se dispusesse a acusar um criminoso para que não houvesse persecução. Destaca-se ainda que o processo era utilizado como instrumento de vingança privada por fomentar acusações levianas, em alguns casos.

Após, passou-se a uma nova cognitio, que se diferenciava da primeira por conferir amplos poderes ao magistrado para investigar, recolher provas e julgar a causa, podendo-se valer da tortura. Como adverte Geraldo Prado, o novo modelo de Roma se distinguirá do inquisitorialismo desenvolvido na Idade Média por prevalecer a forma pública e oral.

Paralelamente aos modelos Romanos, desenvolve-se na antiguidade o modelo Germânico. Num primeiro momento, o sistema germânico não distinguiu o ilícito civil do ilícito penal, considerando toda infração um rompimento da paz, apto a deflagrar a guerra entre os envolvidos, sem ter a intervenção da comunidade. O sistema progrediu de modo e num segundo momento histórico era permitido o "pagamento do preço da paz à comunidade", por meio de convênios reparatórios, e uma indenização ao ofendido ou sua família no caso de infrações menores como bem destaca Geraldo $\operatorname{Prado}^{26}$. É de se ressaltar que o entendimento privado entre os envolvidos era a forma de solução de conflitos que predominava, sendo facultado ao lesado recorrer aos Conselhos, assembléias populares, perante as quais eram desenvolvidos processos judiciais de feição acusatória. Destaca o autor que o processo era deflagrado por iniciativa privada do

\footnotetext{
${ }^{25}$ Ibid. pg. 76.

${ }^{26}$ Ibid..
} 
ofendido ou seus familiares, na hipótese de não ter conseguido alcançar a composição privada. As sessões eram públicas, orais e contraditórias.

O marco de transição do direito antigo para o direito medieval foi a invasão bárbara, por ter fundindo os sistemas jurídicos até então existentes em um tertius gens.

A primeira parte da Idade Média, até o século X aproximadamente, por conta da estrutura feudal, onde predominavam as pequenas comunidades comandadas pelos respectivos Senhores em detrimento dos Reinados, o papel da Justiça, do modo como era concebido em Roma e nos povos Germânicos, foi reduzido ao comando do Senhor Feudal.

Foi a Igreja que teve o papel de centralizar o poder, distribuindo-o em todo o território, através da "jurisdição eclesiástica". A Igreja vê no crime não apenas um problema privado, mas também um problema de salvação da alma, "requisitando-se o magistério punitivo como forma de expiação das culpas" $^{, 27}$.

As ordálias eram vistas na antiguidade como uma forma de devolver à Deus o poder de julgar a causa, submetendo o acusado à provas, cujos resultados seriam a resposta de Deus ${ }^{28}$. Na jurisdição eclesiástica não são mais necessárias as ordálias. A Igreja é uma instituição que representa Deus na Terra, sendo seu mandatário para o julgamento das infrações. Nessa perspectiva, a base dos procedimentos inquisitoriais será a busca da verdade em substituição às ordálias.

A Inquisição teve o mérito histórico de substituir a irracionalidade das ordálias ou juízos de Deus, enquanto sistema de perseguição da verdade, pela busca da reconstituição histórica, procurando reduzir na medida do possível os privilégios da justiça feudal.

As características marcantes da Inquisição foram: forma escrita e secreta, iniciativa oficial para o procedimento e a concentração das três

\footnotetext{
${ }^{27}$ Ibid. p. 80

${ }^{28}$ Haviam várias provas, uma delas noticiada por Fernando de Almeida Pedroso em seu Processo Penal - O direito de defesa: repercussão, amplitudes e limites é a prova do cadáver que consistia em colocar o corpo da vítima diante do acusado e se do cadáver novamente começasse a correr sangue, o réu era havido como verdadeiro autor do homicídio.
} 
funções do processo penal - acusar, defender e julgar - em um só sujeito. A tortura era usada como procedimento investigatório para alcançar a "verdade real". Altera-se o eixo do procedimento e o acusado que era sujeito de direitos passa a ser objeto de investigação como destaca Geraldo Prado.

Nesse modelo, o acusado na grande maioria não tinha defesa, esta era facultativa e dispensável. A uma porque o processo tramitava de forma sigilosa, não tendo o acusado conhecimento de que corre contra si um procedimento criminal. A duas porque da perspectiva dos inquisidores, buscava-se a verdade, não sendo necessária a defesa pois contra esta não havia argumentos.

O modelo inquisitorial se espalhou por toda a Europa. Satisfazia tanto ao clero, por combater as heresias, quanto aos civis, por ser mais eficiente na luta contra a criminalidade.

O sistema inquisitorial ainda encontra raízes em muitos sistemas contemporâneos, todavia, a partir dos séculos XVII e XVIII são amenizadas as características inquisitoriais dos procedimentos penais por conta das idéias do iluminismo.

Destaca-se a Revolução Francesa de 1789 como marco da nova era, representando o triunfo do humanismo sobre o sistema que vigia no Antigo Regime. À luz da Liberdade, Igualdade e Fraternidade, a ciência do Direito será inteiramente reformulada.

Desse período, destacam-se autores como Beccaria, Thomasio, Montesquieu, Voltaire, Bentham e Rousseau, cujas obras representaram marcos teóricos no Direito, sobre a secularização do Direito Penal, separação do Direito da Religião, formulação de teorias sobre a pena, e ainda sobre a separação do poder.

Geraldo Prado informa que a transição política e cultural da monarquia absolutista para a República teve repercussão no processo penal, em especial pela abolição da tortura e a adoção de um sistema processual penal inspirado no aplicado na Roma Republicana. 
O novo sistema, iniciado na França, disciplina o processo penal em duas fases, sendo um sistema de tipo misto. Na primeira fase - juízo de instrução - vigorava o sigilo, onde as atividades eram comandadas por um juiz, chamado de juiz-instrutor tendo como objetivo investigar a infração penal com todas as suas circunstâncias com a finalidade de preparar a ação penal, com atuação tímida da defesa. A segunda fase - juízo - era pública e se desenvolvia perante um tribunal colegiado ou júri onde havia um amplo debate entre acusação e defesa.

O sistema misto permanece na França até os dias atuais, estando presente no atual Code de Procédure Pénale vigente desde 1959, com duas etapas distintas, a primeira secreta, dirigida por um juiz-instrutor e sem defesa e a segunda, pública perante um tribunal, assegurando-se igualdade entre as partes. $\mathrm{O}$ referido modelo se difundiu pela Europa, como na Espanha por exemplo.

O sistema acusatório é caracterizado pela oralidade, separação das funções de acusar e julgar em dois órgãos distintos, e a forma oral como predomínio. Geraldo Prado sintetiza que:

"se pode chamar de acusatório a todo sistema processual que concebe o juiz como um sujeito passivo rigidamente separado das partes e o juízo como uma contenda entre iguais iniciada pela acusação, a quem compete o ônus da prova, enfrentada a defesa em um juízo contraditório, oral e público e resolvida por um juiz segundo sua livre convicção" ${ }^{29}$

No Brasil, o primeiro Código de Processo Criminal Brasileiro foi editado em 1832 ainda sob o império, sob a égide da carta política de 1824. Antes, vigoravam no Brasil as Ordenações Filipinas, Afonsinas e Manuelinas. Antes mesmo das Ordenações, já funcionava um sistema judicial da sociedade indígena onde prevalecia a mediação e, nas palavras de Geraldo Prado, nesse sistema indígena:

"um homem presumidamente culpado era conduzido ao juiz, sem correntes nem algemas de espécie alguma, por mais grave que fosse o delito. Nenhuma pena era aplicada arbitrariamente ou sem prévio inquérito. Cada caso, mesmo pouco

\footnotetext{
${ }^{29}$ PRADO, Geraldo. Op. Cit. pg. 153.
} 
importante, era conscienciosamente estudado. As testemunhas eram ouvidas e acareadas"

A primeira Constituição da República, promulgada em 1891, mirandose no federalismo norte americano, conferia competência à União para legislar sobre direito processual da justiça federal (art. 34;22) de modo que competia à cada Estado membro elaborar o seu próprio Código de Processo Civil e Penal.

A Constituição de 1934 previu a competência exclusiva da União para legislar sobre direito processual (art. 5 $5^{\circ}$ XIX, a), sendo então nomeada, por força do art. 11 das Disposições Transitórias ${ }^{31}$, uma Comissão de Juristas para a elaboração do Código de Processo Penal que foi composta por Cândido Mendes de Almeida, Vieira Braga, Narcélio de Queiroz, Florêncio de Abreu, Roberto Lyra e Nelson Hungria. Do trabalho da Comissão resultou o Código De Processo Penal Brasileiro vigente até hoje com algumas alterações, em especial as efetuadas no ano de 2008.

A doutrina diverge sobre a qualificação do sistema processual adotado pelo Código de Processo Penal vigente. Para José Frederico Marques ${ }^{32}$ o Código teria adotado uma estrutura acusatória enquanto que Hélio Tornaghi ${ }^{33}$ afirma que teria sido adotado um sistema misto tendo em vista que no inquérito policial a apuração do fato e da autoria é feita de forma inquisitória enquanto que o processo judiciário é acusatório em linhas gerais.

A Constituição de 1988 previu o arcabouço do sistema acusatório, conferindo exclusividade ao Ministério Público enquanto instituição autônoma e independente para a deflagração da ação penal, ressalvada a

\footnotetext{
${ }^{30}$ Ibid, p. 168.

${ }^{31}$ Constituição da República Federativa do Brasil de 1934 - art. 11 das Disposições Transitórias: "O Governo, uma vez promulgada esta Constituição, nomeará uma comissão de três juristas, sendo dois ministros da Corte Suprema e um advogado, para, ouvidas as Congregações das Faculdades de Direitos, as Cortes de Apelações dos Estados e os Institutos de Advogados, organizar dentro em três meses um projeto de Código de Processo Civil e Comercial; e outra para elaborar um projeto de Código de Processo Penal. $\S 1^{\circ}$ O Poder Legislativo deverá, uma vez apresentados esses projetos, discuti-los e votá-los imediatamente. §2 ${ }^{\circ}$ Enquanto não forem decretados esses Códigos, continuarão em vigor, nos respectivos territórios, os dos Estados."

${ }^{32}$ MARQUES, José Frederico, apud PRADO, Geraldo. Op. Cit.

${ }^{33}$ TORNAGHI, Hélio, apud PRADO, Geraldo. Op. Cit.
} 
exclusividade extraordinária do ofendido (art. 129), concedeu garantias aos magistrados para lhes conferirem imparcialidade (art. 95) bem como foi previsto o procedimento oral, ao menos para as infrações de menor potencial ofensivo (art. 96). Acrescente-se ainda a previsão expressa da advocacia como função essencial à justiça (art. 133) e a previsão da Defensoria Pública como Instituição essencial à prestação jurisdicional (art. 134).

O Código de Processo Penal ainda é o de 1941, e seus operadores não conseguem por muitas das vezes usar os "óculos da Constituição Cidadã" para interpretá-lo, mesmo com o novo paradigma constitucional e sua hermenêutica expostos no primeiro capítulo. Não é o objeto do presente trabalho avaliar as incongruências estruturais do Código, mas apenas analisar aspectos concernentes ao Direito de Defesa, que será feito nos próximos tópicos.

A propósito dos paradigmas constitucionais vale citar o comentário de Geraldo Prado, para quem

“o princípio e o sistema acusatórios são, por isso, pelo menos por enquanto, meras promessas, que um novo Código de Processo penal e um novo fundo cultural, consentâneo com os princípios democráticos, devem tornar realidade" ${ }^{94}$.

Por fim, após a breve menção a alguns sistemas processuais buscando traçar a caminhada histórica, ressalta-se que no sistema acusatório, a Defesa no Processo Penal deve participar do procedimento, perseguindo a tutela de um interesse que necessita ser oposto à acusação, devendo as regras assegurarem tal escopo.

\subsection{2 - Evolução Histórica do Direito Positivo da Defesa e da assistência jurídica criminal no Brasil;}

No Brasil, a Constituição do Império embora estivesse baseada nos ideais iluministas da época, não contemplou o direito de defesa. Berenice

\footnotetext{
${ }^{34}$ PRADO, Geraldo. Op. Cit. pg. 195.
} 
Maria Giannella informa que uma lei datada de 23.09.1828, fixou regras para o processo penal, determinou a existência de uma acusação formal feita por escrita e a possibilidade de defesa pelo réu, segue o texto da referida lei noticiada pela autora:

" $1^{\circ}$ Em nenhum processo criminal, por mais summario que seja, se proferirá sentença definitiva, ou o réo esteja preso ou solto, sem que a parte acusadora, ou o promotor na falta della, apresente a acusacao por escripto, com especificada menção dos autos e termos do processo, das testemunhas e documentos que fazem culpa; $2^{\circ}$ Que se admitta a contestação do réo, dando-se lugar à prova della, quando for de receber, por apresentar materia de defesa que, provada, releve, sem o que, do mesmo modo, em nenhum processo, por mais summario que seja, se proferira sentença definitiva ..."

A primeira Constituição da República, promulgada em 1891, assegurou o direito de defesa em seu art. $72, \S 16$, previsto na seção que trata da declaração de direitos, com o seguinte teor:

"Aos acusados se assegurará na lei a mais ampla defesa, com todos os recursos e meios essenciais a ela, desde a nota de culpa, entregue em 24 horas ao preso e assinada pela autoridade competente, com os nomes do acusador e das testemunhas. ${ }^{36,}$

A partir de então todas as Constituições brasileiras passaram a prever o direito de defesa como integrante da categoria dos Direitos e Garantias Individuais ou Fundamentais, estando atualmente previsto no art. $5^{\circ}, \mathrm{LV}$ da Carta Cidadã, que estendeu tal direito ao processo administrativo.

A nível internacional, por força dos tratados que o Brasil ratificou, que passam a integrar a ordem jurídica interna, destacamos a Convenção Americana sobre Direitos Humanos, promulgada pelo Decreto 678 de $1992^{37}$ e a Declaração Universal dos Direitos Humanos de $1948^{38}$.

\footnotetext{
${ }^{35}$ GIANNELLA, Berenice Maria. Assistência jurídica no processo penal - garantia do direito de defesa. São Paulo: Editora Revista dos Tribunais, 2002, pg. 101.

${ }^{36}$ CAVALCANTI, Vanuza; BECKER, Antonio. Constituições Brasileiras de 1824 a 1988. Vol. 1. Rio de Janeiro: letra legal editora, 2004. 282 p.

37 "Art. $8^{\circ}$. Garantias Judiciais.

2. Toda pessoa acusada de delito tem direito a que se presuma sua inocência enquanto não se comprove legalmente sua culpa. Durante o processo, toda pessoa tem direito, em plena igualdade, às seguintes garantias mínimas:

c) concessão ao acusado do tempo e dos meios adequados para a preparação de sua defesa;"

${ }^{38}$ Art. 11 - "Toda pessoa acusada de um ato delituoso tem o direito de ser presumida inocente, até que a sua culpabilidade tenha sido provada de acordo com a lei, em julgamento público no qual lhe tenham sido asseguradas rodas as garantias necessárias à sua defesa."
} 
A respeito da assistência jurídica, a primeira regulamentação do patrocínio jurídico gratuito dos hipossuficientes se deu em 1278 na França como assinala Berenice Maria Giannella, destacando ainda que foi a Declaração dos Direitos do Homem e do Cidadão da França de 1789 que transformou a assistência jurídica aos hipossuficientes num direito do homem e um dever do Estado, por conta da Igualdade substancial.

No Brasil, a assistência jurídica tem suas raízes nas Ordenações Filipinas de 1603 que previa a possibilidade de dispensa no pagamento das "custas" e cauções no caso de litigante hipossuficiente.

Todavia, a primeira Constituição Brasileira, de 1824, não previu a assistência jurídica, nem o fez o Código de Processo Penal do Império.

João Henrique Pierangelli ${ }^{39}$ anota que uma lei datada de 1827 ao disciplinar os crimes de responsabilidade dos Ministros e Secretários de Estado previa medidas garantidoras do direito de defesa como por exemplo, a necessidade do acusado ser notificado. De igual modo, o Decreto 27 de 07.01.1892, regulava o processo e julgamento do Presidente da República e dos Ministros de Estados, previa mecanismos de defesa.

Em seguida, a Lei $\mathrm{n}^{\circ} 261$ de 03.12.1841, ao alterar o Código de Processo Criminal do Império, previu a gratuidade de justiça em beneficio dos réus pobres.

Deve-se destacar que até o final do século XIX, o ordenamento jurídico brasileiro tratava apenas da gratuidade de justiça, nada disciplinando sobre a figura do advogado dos hipossuficientes.

Berenice Maria Giannella informa que parte da doutrina atribui a Joaquim Aurélio Barreto Nabuco de Araújo a primeira iniciativa ao criar um Conselho destinado a prestar "assistência judiciária aos indigentes nas causas cíveis e criminais, dando consultas e encarregando a defesa dos seus direitos a alguns membros do Conselho ou Instituto" ${ }^{40}$ quando presidiu o Instituto da Ordem dos Advogados do Brasil em 1870.

\footnotetext{
${ }^{39}$ Pierangelli, João Henrique, apud GIANNELLA, Berenice Maria, op. cit.

${ }^{40}$ GIANNELLA, Berenice Maria. Op. Cit. pg. 23
} 
Contudo, o cargo de "Advogado dos Pobres", remunerado pelo Estado, foi criado em 1880 com o escopo de promover a defesa dos réus indigentes no Processo Penal. Entretanto, o cargo foi extinto em 1884, sem nunca ter sido ocupado.

No inicio do período republicano, ainda no governo provisório, foi editado o Decreto 1.030 de 1890 que no art. 176 autorizava o Ministro da Justiça a organizar uma comissão para a assistência judiciária dos pobres no crime e no cível. Foi o Decreto n 2547 de 1897 que estruturou a assistência judiciária no Distrito Federal.

Destaca-se ainda o Decreto 19.408 de 1930 que criou a Ordem dos Advogados Brasileiros que conferiu aos advogados provisionados o dever de atuar na assistência judiciária aos carentes.

Foi na Constituição de 1934 que a expressão assistência judiciária apareceu pela primeira vez, no art. 113; 32 que dispunha sobre os Direitos e Garantias Individuais: “A União e os Estados concederão aos necessitados assistência judiciária, criando para esse efeito, órgãos especiais assegurando, a isenção de emolumentos, custas, taxas e selos"

O texto constitucional supra transcrito tratou em conjunto da assistência judiciária e da gratuidade de justiça, dois institutos distintos, valendo trazer a distinção feita por Pontes de Miranda, de acordo o qual:

"Assistência judiciária e benefício da justiça gratuita não são a mesma coisa. $\mathrm{O}$ beneficio da justiça gratuita é direito à dispensa provisória de despesas, exercível em relação jurídica processual, perante o juiz que promete a prestação jurisdicional. É instituto de direito pré-processual. A assistência judiciária é a organização estatal, ou paraestatal, que tem por fim, ao lado da dispensa provisória das despesas, a indicação de advogado. É instituto de direito administrativo" $" 42$

O texto de 1937 nada dispôs sobre a matéria em comento por ser fruto de um regime totalitário. No entanto, o assunto foi tratado no Código de Processo Civil de 1939 e do Código de Processo Penal de 1941.

É importante destacar que o Código de Processo Penal vigente, pela primeira vez trouxe de forma expressa a obrigatoriedade do advogado no

\footnotetext{
${ }^{41}$ CAVAlCANTI, Vanuza, Et. Al. Op. Cit.

${ }^{42}$ MIRANDA, Pontes, apud GIANNELLA, Berenice Maria. Op. Cit.
} 
processo criminal, no art. $261^{43}$, prevendo ainda no art. $263^{44}$ que se o acusado não constituir um advogado, o magistrado poderá nomear um. Frise-se que o advogado nomeado pelo juiz não pode recusar o encargo sob pena de arcar com uma multa (art. $264^{45}$ ).

A Constituição de 1946 voltou a tratar do tema, ao prever no art. 141, §35 a obrigação do Poder Público conceder assistência judiciária aos necessitados, não sendo a matéria alterada na Constituição de 1967.

Alargando o espectro da assistência aos hipossuficientes, a Constituição de 1988 previu no art. 5, LXXIV a obrigação do Estado de prestar assistência jurídica "integral e gratuita" aos hipossuficientes, o que abrange além da assistência judiciária, na fase processual, a assistência na fase préprocessual, incluindo atividades consultivas. No Processo Penal significa a assistência na fase de inquérito policial.

Outra novidade da Constituição Cidadã é a institucionalização da Defensoria Pública que aparece pela primeira vez na Constituição, reconhecida no art. 134 como Instituição essencial à função jurisdicional do Estado, sendo obrigatória a sua instalação nos Estados da federação e à nível federal. Cumpre informar que passados mais de 22 anos de sua promulgação ainda há Estados que não contam com Defensorias Públicas como é o caso do Paraná e Goiás por exemplo, cabendo informar ainda que São Paulo, o Estado mais populoso da federação, somente atendeu ao mandamento constitucional em 2006.

Em 1994 foi editada a Lei Orgânica da Defensoria Pública (Lei Complementar 80, recentemente alterada pela Lei Complementar $\mathrm{n}^{\mathbf{o}}$ 132/09), que estrutura a Defensoria Pública da União e do Distrito Federal e dita normas gerais para as Defensorias Públicas Estaduais. Estabelece o

\footnotetext{
${ }^{43}$ Art. 261 - "nenhum acusado, ainda que ausente ou foragido, será processado ou julgado sem defensor."

${ }^{44}$ Art. 263 - "Se o acusado não o tiver, ser-lhe-á nomeado defensor pelo juiz, ressalvado o seu direito de, a todo tempo, nomear outro de sua confiança, ou a si mesmo defender-se, caso tenha habilitação."

${ }^{45}$ Art. 264 - "Salvo motivo relevante, os advogados e solicitadores serão obrigados, sob pena de multa de cem a quinhentos mil-réis, a prestar seu patrocínio aos acusados, quando nomeados pelo juiz".
} 
diploma legal em seu art. $4^{\circ}$ que é função institucional da Defensoria Pública a orientação jurídica e a defesa dos necessitados em todos os graus (I), exercer a curadoria especial nos casos previstos em lei (XVI) bem como o acompanhamento de inquérito policial (XIV), dentre outras ali enumeradas.

A Lei $\mathrm{n}^{\circ}$ 1.060/50 que prevê a isenção das custas, taxas e emolumentos para os hipossuficientes. Ressalvando-se, contudo o entendimento de que se trataria de imunidade tributária decorrente do art. $5^{\circ}$, LXXIV da Constituição da República.

Feita a evolução histórica positiva do direito de defesa e da assistência judiciária no Brasil, passa-se à análise da defesa propriamente dita.

\section{2 - Definição e natureza jurídica da defesa - direito, princípio ou garantia?}

\subsection{1 - Definição e natureza jurídica da defesa}

Para a correta delimitação teórica da defesa deve-se analisar a sua relação com o contraditório.

Em uma visão contemporânea ${ }^{46}$, o contraditório engloba o direito das partes de debater frente ao juiz impondo que seja dada ciência a ambas as partes de todos os atos praticados e que lhes seja assegurado a oportunidade de reação, de manifestarem-se sobre o ato praticado. Candido Rangel Dinamarco $^{47}$ informa que o conceito moderno de processo necessariamente deve envolver o procedimento e o contraditório, sem o que não existe processo.

Por sua vez, Ada Pellegrini Grinover, Antonio Magalhães Gomes Filhos e Antonio Scarance Fernandes ${ }^{48}$ explicam que é do contraditório, em especial da exigência de informação aos litigantes de todos os atos, que

\footnotetext{
${ }^{46}$ JUNIOR, Aury Lopes. Op. Cit.

${ }^{47}$ DINAMARCO, Candido Rangel, apud JUNIOR, Aury Lopes. Op. Cit..

${ }^{48}$ GRINOVER, Ada Pellegrini, et al. As nulidades no Processo Penal. $11^{a}$ edição. São Paulo: Editora Revista dos Tribunais, 2008.
} 
nasce o exercício da defesa. Todavia, enquanto poder correlato ao direito de ação, a defesa garante o contraditório. É por isso que afirmam "a defesa, assim, garante o contraditório, mas também por este se manifesta e é garantida" 49 .

Na tarefa de definir a defesa, parte-se das lições de Piero Calamandrei ${ }^{50}$, processualista civil, cujos conceitos desenvolvidos para aquele ramo do direito podem servir de guia para o Processo Penal.

De acordo com o autor italiano, o direito de defesa está intimamente ligado ao próprio direito de ação, que deve ser visto de forma bilateral. A ação se apresenta como a petição que uma pessoa faz ao órgão judicial de uma providência para atuar na esfera jurídica de outra pessoa, buscando-se na via judicial a sujeição de seu interesse. Pela garantia do contraditório, o demandado pode contradizer os fatos alegados pelo demandante e se estabelece uma relação com o magistrado formulando-lhe pedidos, ainda que de mera improcedência do pedido autoral, também atuando no direito na ação. O impulso e a colaboração chegam dos dois lados ao órgão jurisdicional, isto é vem do autor e do réu. É por isso que o autor afirma que a atividade do demandado pode ser colocada no conceito de ação e o direito de defesa visto como uma das faces do direito de ação, a perspectiva do Réu deste.

Para Carnelutti ${ }^{51}$, a formação do juízo penal segue a ordem da tríade lógica tendo a ação como tese, a defesa como antítese e a decisão judicial como síntese. A defesa contraria a ação ante a jurisdição.

Instaurado o processo, o réu deve assumir uma postura atuante, não como mero espectador ou objeto mas como parte, devendo influir na formação do resultado da atividade jurisdicional.

Fernando de Almeida Pedroso ${ }^{52}$ afirma que o direito de defesa é negativo ao de ação, diversificando-se apenas quanto às conseqüências que

\footnotetext{
${ }^{49}$ Ibid, pg. 69.

${ }^{50}$ CALAMANDREI, Piero. Direito Processual Civil. Volume 1. Campinas: Bookseller, 1999.

${ }^{51}$ CARNELUTTI, Francesco, apud GIANNELLA, Berenice Maria, op cit.
} 
procuram deflagrar. São direitos paralelos e contrapostos. Nessa perspectiva, afirma o autor ser a defesa um direito público, subjetivo, autônomo e abstrato, tal como o direito de ação.

Trata-se de um direito público porque visa à prestação jurisdicional, afeta ao poder público. Subjetivo porque não se apresenta como um dever imposto ao acusado mas sim como uma faculdade. Vale frisar que a facultatividade não significa que haverá processo sem defesa. Não se admite em hipótese alguma processo penal sem defesa. Caso o acusado não constitua um patrono, o Estado deve fornecer-lhe um. Para Fernando de Almeida Pedroso trata-se de uma faculdade onerosa uma vez que a omissão de seu titular não impede lhe seja nomeado um defensor pelo Estado para que a defesa seja exercida mesmo que não o seja com toda a força possível. Por fim, afirma-se que se trata de um direito autônomo porque independe de o acusado possuir efetivo direito que o socorra, sendo abstrato em função de sua autonomia.

Dessa forma, afirma-se com Fernando de Almeida Pedroso que o direito de defesa e o direito de ação em tudo se assemelham, diversificando unicamente a posição dos mesmos dentro da relação processual deduzida em juízo.

\subsection{2 - Direito, princípio ou garantia?}

Classicamente, distinguem-se os direitos das garantias na medida em que os direitos teriam conteúdo declaratório enquanto as garantias seriam os meios para assegurá-los. Para Ruy Barbosa ${ }^{53}$, os direitos seriam disposições meramente declaratórias buscando apenas imprimir a existência legal dos direitos reconhecidos e as garantias seriam disposições assecuratórias.

\footnotetext{
52 PEDROSO, Fernando de Almeida. Processo Penal - O direito de defesa: Repercussão, amplitude e limites. $3^{\mathrm{a}}$ edição. São Paulo: editora revista dos tribunais, 2001.

${ }_{53}$ BARBOSA, Ruy, apud SILVA, José Afonso da. Curso de Direito Constitucional Positivo.
} 
Em que pese a distinção acima referida, verifica-se uma dificuldade de distinção na prática e sobretudo utilidade uma vez que conforme assinalouse no Capítulo 1 do presente estudo, um dos marcos teóricos do constitucionalismo contemporâneo é de reconhecer força normativa à todas as disposições constitucionais, mesmo as meramente declaratórias.

De acordo com a doutrina majoritária ${ }^{54}$ a norma jurídica se divide em regras e princípios que veiculam direitos ou garantias. As regras são predominantemente descritivas, trazendo comandos claros, objetivos e precisos, que não o interprete em dúvida quanto às situações em que deverá incidir nem quanto as consequiências jurídicas nos casos de sua incidência. Os princípios são predominantemente finalístico, indicando um valor, um fim que deve orientar a interpretação de todo o ordenamento jurídico e a atuação concreta do Estado. Nesse ponto, vale trazer a definição construída por Humberto Ávila:

“os princípios são normas imediatamente finalísticas, primariamente prospectivas e com pretensão de complementaridade e de parcialidade, para cuja aplicação se demanda uma avaliação da correlação entre o estado de coisas a ser promovido e os efeitos decorrentes da conduta havida como necessária à sua promoção ${ }^{55}$,

Berenice Maria Giannella afirma que a defesa pode ser vista como direito, princípio ou garantia. Como direito a defesa se especifica no exercício de poderes processuais necessários para defender-se e agir em juízo. Do ponto de vista do acusado seria um direito, dando-se prevalência ao interesse privado do acusado sobre o geral. Enquanto garantia, a defesa existe por conta da exigência de um correto desenvolvimento do processo, em razão de um interesse público geral que transcende o interesse do acusado. A defesa é uma garantia para um processo justo. Por fim, a defesa ainda pode ser vista como princípio por permear todo o sistema processual, informando o andamento do processo penal em cada um de seus momentos em especial por conta de sua ligação com o contraditório.

\footnotetext{
${ }^{54}$ Humberto Ávila acrescenta às regras e princípios os postulados normativos, qualificados como normas de segundo grau que orientam a interpretação e a aplicação das demais normas.

${ }^{55}$ ÁVILA, Humberto. Op. Cit. pg. 78.
} 


\section{3 - Conteúdo do direito de defesa.}

A defesa no Processo Penal se apresenta sob dois aspectos: defesa pessoal (ou autodefesa) e defesa técnica. Afrânio Silva Jardim enfatiza afirmando que o direito de defesa no processo penal é titularizado pelo acusado, quando exerce a sua autodefesa, mas também pelo defensor, com "órgão autônomo", nas palavras de Afrânio: "a defesa é exercida tanto pelo réu, a chamada autodefesa, como pelo seu defensor, a chamada defesa técnica" $" 56$.

Inobstante o presente trabalho estudar a defesa técnica como pano de fundo, deve-se abordar a defesa pessoal por ser um dos substratos da defesa, assegurada de forma ampla à nível constitucional.

\subsection{1 - Defesa Pessoal (autodefesa);}

Diz-se pessoal a defesa do acusado quando ele próprio traz aos autos fatos impeditivos, extintivos ou excludentes da pretensão acusatória para contestar a acusação. É a série de manifestações do próprio réu no decorrer da relação processual.

Vale trazer a advertência feita por Fernando de Almeida Pedroso ${ }^{57}$, de acordo com o qual não se confundem defesa pessoal e autodefesa. Para o autor, esta é o patrocínio próprio, isso é, quando o acusado, possuindo habilitação técnico-jurídico postula em causa própria. A distinção é pertinente, no entanto a maior parte da doutrina utiliza o vocábulo autodefesa para designar a defesa exercida pelo próprio acusado, no sentido que o autor usa para defesa pessoal, sem distinguir uma da outra.

A defesa pessoal constitui um direito do acusado, sendo, portanto, renunciável como afirmou-se supra. Vale frisar que o acusado pode não exercê-lo, mas é obrigatório ao Estado assegurar-lhe pleno exercício sob

\footnotetext{
${ }^{56}$ JARDIM, Afrânio Silva. Direito Processual Penal. 11ª edição. Rio de Janeiro: Forense, 2002, pg. 357.

${ }^{57}$ PEDROSO, Fernando de Almeida, op cit.
} 
pena de nulidade absoluta do processo. Por exemplo, o acusado pode não estar presente no dia de seu interrogatório, no entanto, a ausência só poderá ser interpretada como uma renuncia ao exercício do direito de defesa pessoal se o réu tiver sido regularmente citado do processo e intimado para $\mathrm{o}$ ato.

Antonio Scarance Fernandes ${ }^{58}$ apresenta três manifestações da autodefesa (defesa pessoal): direito de audiência, direito de presença e direito de postular pessoalmente.

O direito de audiência consiste no direito do acusado de apresentar pessoalmente a sua defesa ao juiz da causa, isto é, de apresentar-lhe a sua versão dos fatos, opondo-se à imputação. $\mathrm{O}$ momento oportuno para a sua manifestação é um interrogatório, ocasião em que estará em contato direto com o juiz. Tal manifestação vem garantida expressamente no art. $8^{\circ}, 1$ do Pacto de São José da Costa Rica ${ }^{59}$ que garante ao acusado o direito de ser ouvido perante um tribunal.

O direito de audiência é renunciável, tendo o acusado o direito de permanecer calado no seu interrogatório, não podendo o seu silêncio ser interpretado desfavoravelmente pelo magistrado como preceitua o art. 186 do Código de Processo Penal, e no plenário do Tribunal do Júri, nenhuma das partes pode fazer referência ao silêncio do acusado sob pena de nulidade, nos termos do art. 478, II do Código de Processo Penal.

O direito ao silêncio, entendido como corolário do privilégio da não auto-incriminação e como renúncia ao direito de audiência se opõe ao dever que têm as testemunhas de deporem sobre os fatos com o compromisso de dizer a verdade, sob pena de incidirem nas penas do crime de falso testemunho. $\mathrm{O}$ acusado não tem esse dever. Desse modo, torna-se de

\footnotetext{
${ }^{58}$ FERNANDES, Antonio Scarance. Processo Penal Constitucional. $6^{\text {a }}$ edição. São Paulo: Editora Revista dos Tribunais, 2010.

${ }^{59}$ Decreto n. $678 / 1992$, Art. $8^{\circ}, 1$ do anexo: "Toda pessoa tem direito de ser ouvida com as devidas garantias e dentro de um prazo razoável, por um juiz ou tribunal competente, independente e imparcial, estabelecido anteriormente por lei, na apuração de qualquer acusacao penal formulada contra ela, ou para que se determinem seus direitos ou obrigações de natureza civil, fiscal ou de qualquer outra natureza".
} 
fundamental importância a definição precisa e clara de quem é investigado, sobretudo nas Comissões Parlamentares de Inquérito.

O Egrégio Supremo Tribunal Federal já teve a oportunidade de se pronunciar sobre a hipótese. Na ordem de Habeas Corpus $\mathrm{n}^{\mathbf{0}}$ 89269, relatado pelo Ministro Ricardo Lewandowski, julgado em 2006, foi deferida liminar para que o paciente intimado a depor em Comissão Parlamentar de Inquérito fosse dispensado da assinatura do termo de compromisso por ter indicio, assegurando-lhe o direito de não se auto-incriminar, garantindo-lhe ainda o direito ao silêncio. Segue a ementa do acórdão.

PENAL. PROCESSO PENAL. HABEAS CORPUS. COMISSÃO PARLAMENTAR DE INQUÉRITO - CPI. DIREITO AO SILÊNCIO. TESTEMUNHA. AUTO-ACUSAÇÃO. LIMINAR DEFERIDA PARA DESOBRIGAR A PACIENTE DA ASSINATURA DE TERMO DE COMPROMISSO. PREJUDICIALIDADE SUPERVENIENTE. I - É jurisprudência pacífica no Supremo Tribunal Federal a possibilidade do investigado ou acusado permanecer em silêncio, evitando-se a auto-incriminação. II - Liminar deferida para desobrigar a paciente da assinatura de Termo de Compromisso. III - A realização da oitiva, garantidos os direitos da paciente, implica a prejudicialidade do feito. IV - HC conhecido e julgado prejudicado. ${ }^{60}$

É oportuna ainda a referência ao Habeas Corpus nº89503, relatado pelo Ministro Cesar Peluso, julgado em 03/04/2007, no qual foi reconhecida como ilegal a prisão preventiva decretada com base na recusa do paciente em ir depor em sede policial, segue a ementa do julgado.

AÇÃO PENAL. Prisão preventiva. Réu que não compareceu à delegacia de polícia para depoimento. Fato que lhe não autoriza a custódia cautelar decretada. Ofensa à garantia constitucional de não auto-incriminação. Exercício do direito ao silêncio. Constrangimento ilegal caracterizado. HC concedido. Precedentes. Inteligência do art. $5^{\circ}$, LXIII, da CF, e art. 312 do CPP. O só fato de o réu, quando indiciado ou investigado, não ter comparecido à delegacia de polícia para prestar depoimento, não the autoriza decreto da prisão preventiva. 2. AÇÃO PENAL. Prisão preventiva. Decreto fundado na gravidade do delito e conseqüiente periculosidade presumida do réu. Inadmissibilidade. Razão que não autoriza a prisão cautelar. Precedentes. Inteligência do art. 312 do CPP. É ilegal o decreto de prisão preventiva que se funda na gravidade do delito e na consequente periculosidade presumida do réu. ${ }^{61}$

\footnotetext{
${ }^{60}$ Supremo Tribunal Federal, Habeas Corpus n. 89269, Relator Min. Ricardo Lewandowski, primeira turma, julgado em 21/11/2006.

${ }^{61}$ Supremo Tribunal Federal, Habeas Corpus n. 89503, Relator Min. Cezar Peluso, segunda turma, julgado em 03/04/2007.
} 
A segunda garantia da autodefesa enumerada por Antonio Scarance é o direito de presença, que se manifesta pela oportunidade do acusado acompanhar os atos de instrução. Nesse ponto, cumpre fazer referência à lei 11.690/2008 que alterou a redação do art. 217 do Código de Processo Penal, permitindo a realização de interrogatório por meio de videoconferência quando a presença do acusado na audiência puder causar humilhação, temor ou grave constrangimento à testemunha ou ao ofendido. Inobstante o texto legal dispor que nessas hipóteses o réu é quem prestará depoimento em recinto separado, por meio de videoconferência, para dar efetividade ao direito de defesa, é a testemunha ameaçada ou constrangida quem deverá prestar o depoimento em recinto separado. É este o entendimento de Ada Pellegrini Grinover, Antonio Magalhães Gomes Filho e Antonio Scarance Fernandes ${ }^{62}$.

A última garantia apontada por Scarance é o direito do acusado de postular pessoalmente, como se dá na legitimidade para impetrar habeas corpus, interpor recursos (CPP art. 577), formular pedidos na execução penal, como pedido de progressão de regime (art. 195 lei 7.210/1984). São hipóteses em que o procedimento é deflagrado pelo acusado, sendo necessária a defesa técnica para o seu prosseguimento.

Para viabilizar a autodefesa, torna-se imprescindível a intimação do causado para os atos processuais, não bastando a intimação do patrono.

A violação ao direito do acusado de exercer sua própria defesa constitui causa de nulidade absoluta, presumindo-se o prejuízo por se tratar de violação direta à preceito constitucional como assevera Ada Pellegrini Grinover ${ }^{63}$.

\subsection{2 - Defesa técnica}

A defesa técnica se manifesta pela atuação de um advogado escolhido pelo acusado ou, na sua ausência, de um advogado de ofício (ou dativo) ou um Defensor Público.

\footnotetext{
${ }^{62}$ GRINOVER, Ada Pellegrini, et ali. Op. Cit.

${ }^{63}$ Ibid.
} 
Ao contrário da defesa pessoal, a defesa técnica é indisponível por tratar-se de uma condição de paridade de armas $^{64}$, garantia de um processo justo, não podendo o acusado ser processado e julgado sem defensor sob pena de nulidade absoluta, nos termos dos arts. 261 e 564, III, "c", ambos do Código de Processo Penal. Na hipótese do réu tornar-se revel, será nomeado um defensor pelo juízo.

A indisponibilidade da defesa técnica tem como escopo estabelecer a igualdade entre as partes do processo. Se a acusação é feita por um técnico, conhecedor do ordenamento jurídico, a defesa também deve ficar a cargo de um profissional. Acresce-se que existe um interesse público na apuração do fato imputado ao acusado.

Como corolário da indisponibilidade da defesa técnica, incumbe ao Estado proporcionar a assistência jurídica a quem não puder pagar os custos de um advogado e quem não quiser contratá-lo. Essas duas hipóteses, que originalmente geravam a nomeação de defensores dativos, passaram a ser funções típicas da Defensoria Pública, instituída a nível nacional com a Constituição de 1988 como instituição essencial à função jurisdicional, o que será aprofundado no último capítulo do presente trabalho, valendo, contudo, citar Luigi Ferrajoli, que em 1989, na Itália, ao propor uma teoria sobre o garantismo, escreveu que:

"Naturalmente, "defesa técnica obrigatória" não quer dizer que a assistência de um advogado dotado de capacidade profissional é uma obrigação para o imputado, e sim que é um direito seu, a que ele pode livremente renunciar, restando firme a obrigação do Estado de assegurá-la gratuitamente se o imputado não puder pagar. ${ }^{, 65}$.

A defesa técnica deve ser plena, isto é, deve ser exercida em todas as fases processuais. Tanto é assim, que o procedimento todo está estruturado de modo que a defesa técnica se manifeste sempre após o acusador e antes da decisão. Por exemplo, no procedimento comum ordinário, a reposta à acusação prevista no arts. 396 e 396-A do CPP é obrigatória e está ao

\footnotetext{
${ }^{64}$ Ibid.

${ }^{65}$ FERRAJOLI, Luigi. Direito e razão: teoria do garantismo penal. $3^{\text {a }}$ edição. São Paulo: Editora Revista dos Tribunais, 2010, pg. 565.
} 
menos para parte da doutrina ${ }^{66}$, antes do recebimento da denúncia. Após, será designada a audiência de instrução e julgamento, onde o defensor do acusado poderá formular perguntas a vítima, as testemunhas e ao acusado, bem como pronunciar-se em alegações finais, após as da acusação.

A defesa técnica deve ainda ser assegurada em fase policial, onde o defensor deverá ter acesso a todas as informações constantes nos autos do inquérito policial, ressalvadas as diligencias de caráter sigilosa, e poderá atuar formulando pedidos de diligências (art. 14 do CPP) e recorrendo ao Magistrado no caso de ilegalidades. Nesse sentido foi editada a súmula vinculante $\mathrm{n}^{\mathrm{o}} 14$ pelo Supremo Tribunal Federal ${ }^{67}$ que confere ao defensor o acesso aos autos do inquérito policial, reforçando o disposto no art. $7^{\circ}$, XIV do Estatuto da Ordem dos Advogados do Brasil ${ }^{68}$.

Além de necessária, indisponível e plena, a defesa deve ser efetiva. É preciso que a atividade exercida pelo defensor seja efetiva no sentido de assistir o acusado, praticando os atos processuais com zelo e articulando teses defensivas mais apropriadas para o caso trabalhado.

Foi nesse sentido que a lei 10.792/2003 acrescentou o parágrafo único art. 261 do Código de Processo Penal determinando que todas as manifestações da defesa sejam fundamentadas ${ }^{69}$.

No Supremo Tribunal Federal, destaca-se o enunciado 523 da Súmula de sua jurisprudência dominante de acordo com o qual a ausência de defesa constitui nulidade absoluta enquanto que a sua ausência acarreta nulidade relativa, devendo ser demonstrado o prejuízo. Tal enunciado deve ser lido

\footnotetext{
${ }^{66}$ Por todos, GRINOVER, Ada Pellegrini, et al. Op. Cit.

${ }^{67}$ Supremo Tribunal Federal do Brasil - Súmula Vinculante no 14 "É direito do defensor, no interesse do representado, ter acesso amplo aos elementos de prova que, já documentados em procedimento investigatório realizado por órgão com competência judiciária, digam respeito ao exercício do direito de defesa"

${ }^{68}$ Lei 8.906/94 - art. $7^{\circ}$. "São direitos do advogado:

(...)

XIV - examinar em qualquer repartição policial, mesmo sem procuração, autos de flagrante e de inquérito, findos ou em andamento, ainda que conclusos à autoridade, podendo copiar peças e tomar apontamentos;"

${ }^{69}$ BRASIL, Código de Processo Penal. Art. 261, parágrafo único - "A defesa técnica, quando realizada por defensor público ou dativo, será sempre exercida através de manifestação fundamentada"
} 
com a advertência feita por Ada Pellegrini Grinover ${ }^{70}$ e outros, de que o prejuízo deve ser aferido em relação ao direito de defesa se este foi ou não atendido.

Ainda em relação à efetividade da defesa técnica, não se pode admitir um mesmo defensor para patrocinar em juízo a defesa de dois réus quando as teses são colidentes como advertem Antonio Scarance Fernandes ${ }^{71} \mathrm{e}$ Aury Lopes Junior ${ }^{72}$, entre outros. Foi com esse escopo que a Lei Complementar 132/09 alterou a Lei Orgânica da Defensoria Pública (LC 80/94) acrescentando o art. $4^{\mathrm{o}}-\mathrm{A}^{73}$, determinando ser direito do assistido pela Defensoria Pública ter a atuação de defensores distintos quando houver colidencias nas teses defensivas ou interesses antagônicos.

No tocante a defesa de co-réus por defensor único na hipótese de teses defensivas colidentes, vale informar que o Egrégio Superior Tribunal de Justiça se pronunciou recentemente afirmando que se trata de hipótese de nulidade absoluta. Trata-se do Recurso em Habeas Corpus n²2.034-ES relatado pela Min. Maria Thereza de Asssis Moura, julgado em 19.08.2010 pela $6^{\text {a }}$ Turma. Segue a ementa do julgado.

PROCESSUAL PENAL. RECURSO ORDINÁRIO EM HABEAS CORPUS. ATENTADO VIOLENTO AO PUDOR. COLIDÊNCIA DE DEFESAS. DEFENSOR ÚNICO PARA O ATO. NULIDADE ABSOLUTA. RECURSO PARCIALMENTE PROVIDO.

I. Reconhecida pelo tribunal de origem a colidência de defesa, há que se declarar a nulidade do ato em que os réus foram assistidos pelo mesmo advogado.

II. A nulidade, segundo a melhor doutrina, é absoluta, prescindindo da demonstração do prejuízo.

III. Recurso parcialmente provido. ${ }^{74}$

Ainda em relação à efetividade da defesa técnica, deve-se advertir que o art. 497, V do Código de Processo Penal, que prevê a possibilidade do magistrado declarar o réu indefeso, destituindo o patrono, deve ser aplicado

\footnotetext{
${ }^{70}$ GRINOVER, Ada Pellegrini, et al. Op cit.

${ }^{71}$ FERNANDES, Antonio Scarance, Op Cit.

72 JUNIOR, Aury Lopes, op cit.

${ }^{73}$ Lei Complementar 80/94 - "Art. $4^{\circ}$-A - São direitos dos assistidos da Defensoria Pública, além daqueles previstos na legislação estadual ou em atos normativos internos:

(...)

V - a atuação de Defensores Públicos distintos, quando verificada a existência de interesses antagônicos ou colidentes entre destinatários de suas funções;"

${ }^{74}$ Superior Tribunal de Justiça, Recurso em Habeas Corpus n. 22.034, Rel. Ministra Maria Thereza de Assis Moura, sexta turma, julgado em 19.08.2010.
} 
a todos os procedimentos. No entanto, na hipótese de ser destituído o causídico, deve ser assegurado ao acusado a possibilidade de escolha de um novo patrono por ter direito à sua livre escolha.

É importante ainda deixar claro que é direito do acuado a livre escolha de seu defensor em razão da necessária relação recíproca de confiança. Dessa forma, quando o defensor deixa de realizar os atos que lhe são próprios, como por exemplo, as alegações finais no caso que deveriam ser apresentadas por memoriais, o magistrado deve intimar o acusado para constitui outro defensor. Somente na hipótese do réu quedar-se inerte é que poderá ser nomeado defensor dativo. Nesse ponto, vale conferir o Habeas Corpus n86260, julgado pela segunda turma do Egrégio Supremo Tribunal Federal em 19.06.08, relatado pelo Ministro Cezar Peluso, em que resta claro que o acusado tem o direito de escolher o seu defensor sob pena de cerceamento de defesa.

Em relação ao direito de eleição do defensor, cumpre citar o enunciado 708 da súmula do Supremo Tribunal Federal ${ }^{75}$ de acordo com a qual no caso no caso do patrono renunciar ao mandato no momento de apresentar as razões recursais, o tribunal deve intimar o acusado para constituir um novo sob pena de nulidade absoluta.

Assim, pode-se afirmar que a defesa técnica é indisponível e só atenderá ao mandamento constitucional se for plena e efetiva, e de escolha do defensor livre pelo acusado.

\subsection{3 - Relações entre defesa pessoal e defesa técnica;}

Normalmente as relações entre Defensor e acusado são pautadas pela confiança e as suas práticas devem convergir na mesma direção, seguindo a mesma tese defensiva. A defesa técnica deve dar a roupagem jurídica à autodefesa. Nem sempre é assim. Inobstante a observância da entrevista

\footnotetext{
${ }^{75}$ Supremo Tribunal Federa, enunciado 708 da súmula de sua jurisprudência dominante: "É nulo o julgamento da apelação se, após a manifestação nos autos da renúncia do único defensor, o réu não foi previamente intimado para constituir outro".
} 
prévia do Defensor com o acusado antes do interrogatório, é possível que a defesa técnica e a autodefesa sigam rumos opostos. A situação é bastante comum no caso de acusado defendido por Defensor Público, como por exemplo na hipótese em que o acusado negar a autoria do fato que lhe é imputado e o defensor alegar legitima defesa como tese defensiva.

Analisando a hipótese em questão, Ada Pellegrini Grinover ${ }^{76}$ informa que não é correto afirmar que deve prevalecer a defesa técnica em detrimento da autodefesa. Em primeiro lugar, deve-se verificar se o comportamento do defensor não deixou o réu indefeso, hipótese em que dever-se-ia invocar o art. 497, V do CPP, anulando-se o processo por prejuízo a defesa. Caso não ocorra a anulação do processo, todas as teses defensivas deverão ser apresentadas pelo juiz, ainda que contraditórias, sob pena de nulidade, orientando-se pelo sistema do livre convencimento motivado.

Nesse sentido, destaca-se decisão do Superior Tribunal de Justiça, proferida no Habeas Corpus 34.350-MS, de relatoria do Ministro Hélio Barbosa, julgado em 07.10.2004 no qual restou consignado que a colidência entre a autodefesa e a defesa técnica deve ser analisada à luz do enunciado 523 da súmula do Supremo Tribunal Federal, isto é, analisar se houve defesa e se esta foi deficiente ou não.

Outra é a situação no caso de divergência entre defensor e acusado no caso do desejo de recorrer. Nesse caso, prevalece na doutrina e na jurisprudência que deve ser considerada a posição mais benéfica para o réu. Afinal, caso o réu tenha se conformado com a sentença condenatória e o defensor interponha o recurso de apelação, a situação jurídica do acusado não poderá piorar por conta da vedação da reformatio in pejus. Frise-se ainda que como bem destaca Afrânio Silva Jardim, o defensor tem legitimidade própria para recorrer (art. $577 \mathrm{CPP}$ ).

\footnotetext{
${ }^{76}$ GRINOVER, Ada Pellegrini, et al.Op. Cit.
} 


\section{3 - O DEFENSOR DATIVO}

Em relação a terminologia adotada, vale trazer a distinção lembrada por Eugênio Pacelli de Oliveira ${ }^{77}$ entre defensor dativo e defensor ad hoc. O primeiro é o nomeado pelo Estado para quem não puder ou não quiser constituir advogado e o segundo é o designado especificamente para a prática de determinado ato processual, na ausência do defensor dativo ou constituído. Inobstante a pertinência da distinção, no presente trabalho utiliza-se o termo defensor dativo de forma genérica para designar todas as hipóteses em que o defensor é nomeado pelo magistrado, em oposição ao defensor constituído. A possibilidade de o magistrado nomear um defensor decorre da imprescindibilidade da defesa técnica como visto no capítulo 2.

A seguir, examinaremos as hipóteses legais em que o magistrado é autorizado a nomear o defensor para o acusado, em seguida interpretaremos os dispositivos à luz das conclusões e modelos traçados nos dois primeiros capítulos do presente.

\section{1 - Previsão normativa do defensor dativo no código de Processo Penal;}

O Código de Processo Penal trata do defensor nos arts. 259 a 267. No art. 261, deixa claro que nenhum acusado será processado ou julgado sem defensor, no art. $265, \S 1^{\circ}$ prevê a possibilidade de adiar a audiência se o defensor não puder comparecer por motivo justificado e no $\S 2^{\circ}$ do mesmo artigo a possibilidade do magistrado nomear defensor substituto se o defensor constituído não provar o impedimento até a abertura da audiência, deixando claro que não deve ser adiado nenhum ato processual ${ }^{78}$. O

\footnotetext{
${ }^{77}$ OLIVEIRA, Eugênio Pacelli. Curso de Processo Penal. 10a edição. Rio de Janeiro: Lumen Juris, 2008.

78 “Art. 265. (...)

$\S 1^{\circ}$ - A audiência poderá ser adiada se, por motivo justificado, o defensor não puder comparecer.
} 
anteprojeto do novo Código de Processo Penal traz algumas diferenças que serão abordadas no item 2 do presente capítulo.

Os dispositivos acima transcritos tiveram a redação determinada pela lei 11.719/08. Antes da alteração legislativa, o parágrafo único do art. 265 dispunha que a falta do defensor, ainda que motivada, não ensejaria o adiamento do ato, devendo-se nomear um defensor dativo para o ato, vejamos a redação pretérita:

“Art. 265. (...)

Parágrafo único - A falta de comparecimento do defensor, ainda que motivada, não determinará o adiamento de ato algum do processo, devendo o juiz nomear substituto, ainda que provisoriamente ou para o só efeito do ato."

Pela simples transcrição dos dispositivos, percebe-se uma mudança favorável à efetividade do direito de defesa, na medida em que há a possibilidade expressa da audiência ser adiada caso o defensor prove um "justo impedimento" até a abertura da audiência.

Vale frisar que a mudança legislativa apenas consolidou $o$ entendimento doutrinário e jurisprudencial já consolidado, fundamentado no direito de defesa, invocando-se analogicamente o Código de Processo Civil que prevê no art. 453, II $^{79}$ a possibilidade de adiamento da audiência no caso do advogado não poder comparecer por "motivo justificado", a ser comprovado até a abertura da audiência.

Guilherme de Souza Nucci, ao comentar a redação original do parágrafo único do art. 265 afirmava que:

"Diz a lei que a falta de comparecimento não determinará o adiamento do ato, ainda que seja ausência motivada. Essa situação configura exagero, podendo implicar sério gravame ao direito à ampla defesa, que todo réu possui. Se o defensor comunicar

$\S 2^{\circ}$ - Incumbe ao defensor provar o impedimento até a abertura da audiência. Não o fazendo, o juiz não determinará o adiamento de ato algum do processo, devendo nomear defensor substituto, ainda que provisoriamente ou só para o efeito do ato."

79 “Art. 453 - A audiência poderá ser adiada:

I - por convenção das partes, caso em que só será admissível uma vez;

II - se não puderem comparecer, por motivo justificado, o perito, as partes, as testemunhas ou os advogados.

$\S 1^{\circ}$ Incumbe ao advogado provar o impedimento até a abertura da audiência; não o fazendo, o juiz procederá à instrução" 
com antecedência a sua impossibilidade de comparecer, fornecendo motivo justo, é curial que o juiz adie o ato - desde que não exista prejuízo (como a ocorrência da prescrição ou excesso de prazo na formação da culpa) - evitando afetar a defesa do acusado." 80

Ao tratar do procedimento especial relativo aos processos da competência do tribunal do júri, o Código de Processo Penal tem uma regra diversa no art. 456, com redação dada pela lei 11.689 de $2008^{81}$. Se o advogado do acusado faltar à sessão de julgamento, não tendo o acusado constituído um novo advogado, o magistrado deve adiar a audiência, comunicando o fato à Ordem dos Advogados do Brasil e intimar a Defensoria Pública da nova data designada para que na hipótese de haver nova ausência, assuma a defesa do acusado. Os comentários à este dispositivo, em especial a posição institucional da Defensoria Pública do Estado do Rio de Janeiro serão apresentados no próximo tópico. Vale mencionar que no anteprojeto do Código de Processo Penal (PLS 156), o art. 358 tem a mesma redação do atual art. 456.

\subsection{Interpretação conforme a Constituição}

Nesse item serão interpretadas as hipóteses em que se permite a nomeação de defensor pelo magistrado, bem como a escolha deste, à luz das conclusões construídas nos dois primeiros capítulos.

No caso de abandono do processo pelo defensor constituído, os tribunais são uníssonos em afirmar que antes de nomear um defensor dativo, o magistrado deve oportunizar ao acusado a faculdade de escolha de

\footnotetext{
${ }^{80}$ NUCCI, Guilherme Souza. Código de Processo Penal Comentado. $5^{\mathrm{a}}$ edição. São Paulo: Editora Revista dos Tribunais, 2006, pg. 264.

81 "Art. 456. Se a falta, sem escusa legítima, for do advogado do acusado, e se outro não for por este constituído, o fato será imediatamente comunicado ao presidente da seccional da Ordem dos Advogados do Brasil, com a data designada para a nova sessão.

$\S 1^{\circ}$ - Não havendo escusa legítima, o julgamento será adiado somente uma vez, devendo o acusado ser julgado quando chamado novamente.

$\S 2^{\circ}$ - Na hipótese do $\S 1^{\circ}$ deste artigo, o juiz intimará a Defensoria Pública para o novo julgamento, que será adiado para o primeiro dia desimpedido, observado o prazo mínimo de 10 (dez) dias."
} 
um novo patrono, intimando-o para tal finalidade. Caso não constitua, poderá ser nomeado um defensor pelo magistrado. Como exemplo, citamos o Habeas Corpus n. 162.785/AC julgado pela $5^{\mathrm{a}}$ Turma do Superior Tribunal de Justiça em 13.04.2010, relatado pelo Ministro Napoleão Nunes Maia Filho em que restou consignado que fulmina de nulidade absoluta o feito em que é nomeado defensor dativo, sem a prévia intimação do réu para que indique se deseja constituir um novo patrono. Segue a ementa do julgado.

HABEAS CORPUS. HOMICÍDIO DUPLAMENTE QUALIFICADO. RÉU REVEL. FALECIMENTO DO ADVOGADO DE DEFESA. NOMEAÇÃO DE DEFENSOR DATIVO SEM PRÉVIA INTIMAÇÃO DO RÉU PARA A INDICAÇÃO DE ADVOGADO DE CONFIANÇA. NULIDADE ABSOLUTA. PRECEDENTES DO STJ. PARECER DO MPF PELA CONCESSÃO DO WRIT. ORDEM CONCEDIDA, PARA ANULAR O FEITO A PARTIR DA DECISÃO QUE NOMEOU O DEFENSOR DATIVO, MANTIDA A PRISÃO DO PACIENTE.

1.A escolha de defensor, de fato, é um direito inafastável do réu, porquanto deve haver uma relação de confiança entre ele e o seu patrono. Assim, é de rigor que uma vez verificada a ausência de defesa técnica a amparar o acusado, por qualquer motivo que se tenha dado, deve-se conceder prazo para que o réu indique outro profissional de sua confiança, ainda que revel, para só então, caso permaneça inerte, nomear-lhe defensor dativo.

2.Habeas Corpus concedido, nos termos do parecer ministerial, para anular o feito a partir da decisão que nomeou o defensor dativo, a fim de que seja oportunizado ao réu a indicação de advogado de sua confiança, mantido paciente na situação processual em que se encontra.

É na hipótese de ausência do defensor constituído em determinado ato processual que a legislação, a jurisprudência e a doutrina se distanciam do modelo constitucional.

Como mencionamos acima, de acordo com a regra geral, na ausência do defensor constituído o magistrado deve nomear um para a prática do ato, se o acusado não constituir um novo. Somente não poderá ser nomeado um novo defensor se o constituído provar o impedimento até o inicio da audiência (art. $265 \mathrm{CPP})$.

Há ainda na doutrina quem sustente que não assiste ao defensor e ao acusado o direito de adiar o ato caso prove, com antecedência, a presença 
de "justo impedimento" para a realização do ato. É esta a posição defendida por Fernando de Almeida Pedroso que tem obra especifica sobre o direito de defesa, citada diversas vezes ao longo do presente, vale transcrever o pensamento do autor:

"Quid inte, nesse caso, se o Magistrado, não obstante a solicitação de adiamento e a prova da impossibilidade de comparecimento do advogado constituído, realizar o ato designado (audiência, exemplificativamente) com a nomeação de defensor ad hoc?

Temos para nós que nulidade alguma desapontará." 82

Hoje, pela redação do art. 265, trata-se de interpretação contra legem que viola ainda a garantia da ampla defesa.

$\mathrm{Na}$ hipótese de não ter sido apresentada justificativa até a abertura da audiência, nem constituído um novo pelo acusado, deve ser nomeado um defensor dativo pelo magistrado, ao menos para aquele ato. $\mathrm{O}$ dispositivo não pode ser interpretado gramaticalmente.

Com a lei 11.719/08, no procedimento comum, todos os atos da instrução foram concentrados em uma audiência uma de instrução e julgamento, onde são ouvidas a vítima, as testemunhas arroladas pelo Ministério Público e pela defesa bem como interrogado o Réu, feitas as alegações finais orais e prolatada a sentença, na mesma audiência.

Caso o advogado constituído, regularmente intimado falte à audiência de instrução e julgamento deverá ser nomeado um pelo magistrado no momento, para a realização da audiência, onde se concentram todos os atos de instrução? Estaria assim preservada a ampla defesa por ter-lhe sido assegurado um defensor?

Afirmou-se no capítulo anterior que a defesa técnica além de indispensável deve ser efetiva. Não é possível que um defensor nomeado pelo magistrado minutos antes da audiência de instrução e julgamento defenda de forma efetiva um acusado de uma acusação que acaba de tomar

\footnotetext{
${ }^{82}$ PEDROSO, Fernando de Almeida, Op. Cit. Pg. 210.
} 
conhecimento, sem nem conhecer o acusado. Caso seja nomeado, o processo será nulo por ausência de defesa.

No caso de ausência do Ministério Público, titular da pretensão acusatória, é vedada a nomeação de promotor ad hoc nos termos do art. 129, §2 da Constituição da República que prevê aos membros do Ministério Público a exclusividade no exercício de suas funções.

A defesa tem natureza de direito e garantia fundamental, sendo assegurada de forma ampla, com todos os recursos à ela inerentes, na Constituição da República. Como visto, a defesa técnica é indisponível, plena e efetiva, e tendo por escopo servir de instrumento para a paridade de armas, isto é, instrumento para a igualdade das partes. No sistema acusatório, o acusado é sujeito de direitos, não podendo ser sacrificado o seu direito de defesa pela ausência do defensor constituído.

Ao tratar do procedimento dos crimes de competência do tribunal do júri, o Código de Processo Penal prevê o adiamento no caso de ausência do defensor constituído.

Nesse ponto, o anteprojeto do Código de Processo Penal, que deu origem ao PLS 156/09, traz uma regra nova ${ }^{83}$. De acordo com o art. $61, \S 2^{\circ}$ do anteprojeto, de acordo com a complexidade da causa e do ato a ser praticado o magistrado pode determinar o adiamento do ato para a atuação do defensor dativo. Tal previsão visa conferir efetividade ao direito de defesa.

Nos Estados onde tenha Defensoria Pública instituída e nas seções judiciárias onde a Defensoria Pública Federal atue, a função de defesa "dativa" deve ser exercida de forma exclusiva e privativa pelos membros da

\footnotetext{
83 “Art. 61. O não comparecimento do defensor não determinará o adiamento de ato algum do processo, devendo o juiz nomear outro em substituição, para o adequado exercício da defesa. $\S 1^{\circ}$ A audiência poderá ser adiada se, por motivo devidamente justificado até a sua abertura, o defensor não puder comparecer.

$\S 2^{\circ}$ Tratando-se de instrução relativa a matéria de maior complexidade probatória, a exigir aprofundado conhecimento da causa, o juiz poderá adiar a realização do ato, com a designação de defensor, para os fins do disposto no caput deste artigo."
} 
Defensoria Pública, que é a Instituição criada pela Constituição com a missão de prestar assistência jurídica aos hipossuficientes. No caso de ausência de defensor constituído, o acusado encontra-se em situação de hipossuficiência técnica, a invocar a atuação da Defensoria Pública.

Para defender a exclusividade da Defensoria Pública no exercício da defesa dativa invoca-se ainda o art. $4^{\circ}$, XVI da Lei Complementar 80/94 ${ }^{84}$ (com redação dada pela Lei Complementar 132/09) que prevê como função institucional da Defensoria Pública o exercício da curadoria especial.

No processo civil, o curador especial tem a natureza de representante judicial, visa suprir a incapacidade processual do réu, nas hipóteses previstas no art. $9^{\circ}$ do Código de Processo Civil. Freddie Didier Junior ao tratar do curador especial afirma: "trata-se de um representante nomeado ad hoc pelo magistrado, com o objetivo de cuidar dos interesses do incapaz processual durante a causa" ${ }^{\prime \prime}$.

Apesar de se tratarem de situações diversas, se no Processo Civil a curadoria especial é exercida com exclusividade pela Defensoria Pública, no Processo Penal, a defesa dativa deve ser exercida exclusivamente pela Defensoria Pública em razão dos interesses em disputa.

Vale ainda mencionar que na hipótese de nomeação de defensor dativo pelo magistrado, no caso de ausência do defensor, sendo adiado o ato processual a ser praticado, o defensor dativo somente poderá atuar se o defensor constituído for destituído pelo Magistrado, ou pelo próprio acusado isto porque não é possível a atuação concomitante de dois defensores, em especial se a defesa dativa for exercida pela Defensoria Pública, como é defendido no presente trabalho.

\footnotetext{
84 “Art. $4^{\text {O }}$ - São funções institucionais da Defensoria Pública, dentre outras:

(...)

XVI - exercer a curadoria especial nos casos previstos em lei;"

${ }^{85}$ JUNIOR, Freddie Didier. Curso de Direito Processual Civil. Volume 1. $12^{\mathrm{a}}$ edição. Salvador: Editora Jus Podium, 2010. Pg 255.
} 
A indispensabilidade da defesa técnica já está consagrada no texto legal e nos tribunais, resta a luta pela sua efetividade. Não basta assegurar formalmente a presença de um defensor, deve-se garantir a efetividade de seu trabalho. 


\section{CONCLUSÃO}

O Estado Constitucional de Direito, surgido após a Segunda Guerra Mundial, tem como principal característica a centralidade da Constituição. A construção do modelo contemporâneo tem como marco histórico o pósguerra na Europa e a redemocratização do Brasil. O marco filosófico do novo modelo constitucional foi o pós-positivismo. Por fim, três mudanças de paradigma assinalam o marco teórico: a força normativa da Constituição, a expansão da jurisdição constitucional e o desenvolvimento de uma nova interpretação Constitucional. A constitucionalização do direito é um dos desdobramentos do neo-constitucionalismo, que se realiza, sobretudo, pela interpretação conforme a Constituição. No Processo Penal significa a incorporação dos valores trazidos pela Carta Constitucional, em especial na adequação dos dispositivos infraconstitucionais ao sistema acusatório consagrado pela Constituição.

No novo cenário, o Processo Penal não pode ser visto como um instrumento a serviço do poder punitivo, mas como um instrumento limitador do poder punitivo estatal e garantidor do individuo a ele submetido. A instrumentalidade do Processo Penal tem por conteúdo a máxima eficiência dos direitos e garantias fundamentais da Constituição, à luz do valor absoluto da dignidade da pessoa humana

Ao longo da história sucederam-se diversos modelos de Processo Penal. No entanto, pode-se distinguir dois sistemas processuais, o inquisitório, caracterizado pela concentração em uma mesma pessoa as funções de acusar, defender e julgar, secreto e escrito, e o sistema acusatório tendo como características básicas a separação das funções de acusar, julgar e defender, publico e oral. No Brasil, a Constituição de 1988 adotou o sistema acusatório, no entanto, o texto infraconstitucional continua de conteúdo inquisitório, podendo-se afirmar que se trata de um sistema inquisitório de estrutura acusatória. 
A defesa foi assegurada constitucionalmente pela primeira vez na primeira Carta Republicana, sendo mantida nas demais Constituições. Não basta a previsão normativa, é necessário assegurar a sua efetividade, o que é possível, ao menos doutrinariamente, a partir da nova hermenêutica constitucional.

A defesa guarda intima relação com o contraditório, sendo uma das formas de assegurá-lo Afirma-se ainda que a defesa é um direito público, subjetivo, autônomo e abstrato, tal como o direito de ação.

A defesa pode ser vista como direito, princípio ou garantia. Como direito a defesa se especifica no exercício de poderes processuais necessários para defender-se e agir em juízo. Do ponto de vista do acusado seria um direito, dando-se prevalência ao interesse privado do acusado sobre o geral. Enquanto garantia, a defesa existe por conta da exigência de um correto desenvolvimento do processo, em razão de um interesse público geral que transcende o interesse do acusado. A defesa é uma garantia para um processo justo. Por fim, a defesa ainda pode ser vista como princípio por permear todo o sistema processual, informando o andamento do processo penal em cada um de seus momentos em especial por conta de sua ligação com o contraditório.

A ampla defesa assegurada pelo texto constitucional se apresenta sob dois aspectos: defesa pessoal (ou autodefesa) e defesa técnica. A primeira é exercida diretamente pelo acusado, é disponível e engloba o direito de audiência, de presença e de postular em nome próprio diretamente para certos atos. A defesa técnica é exercida por profissional habilitado, com capacidade postulatória e visa assegurar a igualdade entre as partes processuais. A defesa técnica é indisponível, devendo ser assegurada pelo Estado à todos que não tem condições de contratar um defensor. Deve ser plena, isto é, assegurada em todas as fases processuais, e ainda no momento 
pré-processual. E, por fim, deve ser efetiva, não basta uma defesa meramente formal.

A previsão da possibilidade de nomeação de defensor dativo pelo magistrado visa assegurar a indisponibilidade defesa técnica. No entanto, os dispositivos devem ser interpretados de modo a assegurar de forma prioritária a efetividade da defesa técnica, sob pena de violar o mandamento constitucional. 


\section{BIBLIOGRAFIA}

\section{Livros}

BARROSO, Luis Roberto. Curso de Direito Constitucional Contemporâneo: os conceitos fundamentais e a construção do novo modelo. São Paulo: Saraiva, 2009. 451 p.

BARROSO, Luis Roberto. O Controle de Constitucionalidade no Direito Brasileiro. $2^{\mathrm{a}}$ edição. São Paulo: Saraiva, 2007. 333 p.

BARROSO, Luis Roberto. Interpretação e aplicação da Constituição. $6^{\mathrm{a}}$ edição. São Paulo: Saraiva, 2004. 427 p.

CINTRA, Antonio Carlos de Araujo; GRINOVER, Ada Pellegrini; DINAMARCO, Cândido Rangel. Teoria Geral do Processo. $23^{\mathrm{a}}$ edição. São Paulo: Malheiros, 2007.383 p.

JUNIOR, Aury Lopes. Direito Processual Penal e sua conformidade Constitucional. $5^{\text {a }}$ edição. Rio de Janeiro: Lumen Juris, 2010. 713 p.

GRECO, Leonardo. Instituições de processo civil. $2^{\mathrm{a}}$ edição. Volume I. Rio de Janeiro: Forense, 2010. 578 p.

PRADO, Geraldo. Sistema acusatório - A conformidade constitucional das leis processuais penais. $4^{\mathrm{a}}$ edição. Rio de Janeiro: Lumen Juris, 2006. 270 p.

GIANNELLA, Berenice Maria. Assistência jurídica no processo penal garantia do direito de defesa. São Paulo: Editora Revista dos Tribunais, 2002. $221 \mathrm{p}$.

CAVALCANTI, Vanuza; BECKER, Antonio. Constituições Brasileiras de 1824 a 1988. Vol. 1. Rio de Janeiro: letra legal editora, 2004. 282 p. 
GRINOVER, Ada Pellegrini; FILHO, Antonio Magalhães Gomes; FERNANDES, Antonio Scarace. As nulidades no Processo Penal. 11 edição. São Paulo: Editora Revista dos Tribunais, 2008. 297 p.

CALAMANDREI, Piero. Direito Processual Civil. Volume 1. Campinas: Bookseller, 1999. $333 \mathrm{p}$.

PEDROSO, Fernando de Almeida. Processo Penal - $O$ direito de defesa: Repercussão, amplitude e limites. $3^{\mathrm{a}}$ edição. São Paulo: Editora Revista dos Tribunais, 2001. $421 \mathrm{p}$.

SILVA, José Afonso da. Curso de Direito Constitucional Positivo. 24 edição. São Paulo: Malheiros Editores, 2004. 924 p.

ÁVILA, Humberto. Teoria dos Princípios, da definição à aplicação dos princípios jurídicos. 5a edição. São Paulo: Malheiros Editores, 2006. 175 p.

JARDIM, Afrânio Silva. Direito Processual Penal. 11 a edição. Rio de Janeiro: Forense, 2002. 431 p.

FERNANDES, Antonio Scarance. Processo Penal Constitucional. $6^{\text {a }}$ edição. São Paulo: editora revista dos tribunais, 2010. 348 p.

FERRAJOLI, Luigi. Direito e razão: teoria do garantismo penal. $3^{\text {a }}$ edição. São Paulo: Editora Revista dos Tribunais, 2010. 925 p.

OLIVEIRA, Eugênio Pacelli. Curso de Processo Penal. 10 edição. Rio de Janeiro: Lumen Juris, 2008. 781 p.

NUCCI, Guilherme Souza. Código de Processo Penal Comentado. $5^{\mathrm{a}}$ edição. São Paulo: Editora Revista dos Tribunais, 2006. 1.213 p.

JUNIOR, Freddie Didier. Curso de Direito Processual Civil. 12 $2^{\mathrm{a}}$ edição. Volume 1. Salvador: Editora Jus Podium, 2010. 618 p. 


\section{Decisões judiciais}

Supremo Tribunal Federal, Habeas Corpus n. 89269, Relator Min. Ricardo Lewandowski, primeira turma, julgado em 21/11/2006.

Supremo Tribunal Federal, Habeas Corpus n. 89503, Relator Min. Cezar Peluso, segunda turma, julgado em 03/04/2007.

Superior Tribunal de Justiça, Recurso em Habeas Corpus n. 22.034, Rel.

Ministra Maria Thereza de Assis Moura, sexta turma, julgado em 19.08.2010 